\title{
Cloud microphysics and aerosol indirect effects in the global climate model ECHAM5-HAM
}

\author{
U. Lohmann ${ }^{1}$, P. Stier ${ }^{2}$, C. Hoose ${ }^{1}$, S. Ferrachat ${ }^{1}$, S. Kloster ${ }^{3}$, E. Roeckner ${ }^{4}$, and J. Zhang ${ }^{5}$ \\ ${ }^{1}$ Institute of Atmospheric and Climate Science, ETH Zurich, Switzerland \\ ${ }^{2}$ Department of Environmental Science and Engineering, California Institute of Technology, Pasadena, USA \\ ${ }^{3} \mathrm{EC}$, Joint Research Centre, IES, Climate Change Unit, Ispra, Italy \\ ${ }^{4}$ Max Planck Institute for Meteorology, Hamburg, Germany \\ ${ }^{5}$ Meteorological Service of Canada, Toronto, Canada
}

Received: 22 February 2007 - Published in Atmos. Chem. Phys. Discuss.: 12 March 2007

Revised: 7 June 2007 - Accepted: 18 June 2007 - Published: 2 July 2007

\begin{abstract}
The double-moment cloud microphysics scheme from ECHAM4 that predicts both the mass mixing ratios and number concentrations of cloud droplets and ice crystals has been coupled to the size-resolved aerosol scheme ECHAM5HAM. ECHAM5-HAM predicts the aerosol mass, number concentrations and mixing state. The simulated liquid, ice and total water content and the cloud droplet and ice crystal number concentrations as a function of temperature in stratiform mixed-phase clouds between 0 and $-35^{\circ} \mathrm{C}$ agree much better with aircraft observations in the ECHAM5 simulations. ECHAM5 performs better because more realistic aerosol concentrations are available for cloud droplet nucleation and because the Bergeron-Findeisen process is parameterized as being more efficient.

The total anthropogenic aerosol effect includes the direct, semi-direct and indirect effects and is defined as the difference in the top-of-the-atmosphere net radiation between present-day and pre-industrial times. It amounts to $-1.9 \mathrm{~W} \mathrm{~m}^{-2}$ in ECHAM5, when a relative humidity dependent cloud cover scheme and aerosol emissions representative for the years 1750 and 2000 from the AeroCom emission inventory are used. The contribution of the cloud albedo effect amounts to $-0.7 \mathrm{~W} \mathrm{~m}^{-2}$. The total anthropogenic aerosol effect is larger when either a statistical cloud cover scheme or a different aerosol emission inventory are employed because the cloud lifetime effect increases.
\end{abstract}

\section{Introduction}

Aerosol effects on warm clouds by increasing the cloud droplet number concentration and decreasing cloud droplet

Correspondence to: U. Lohmann

(ulrike.lohmann@env.ethz.ch) size have been considered in climate models for more than a decade (Jones et al., 1994; Boucher and Lohmann, 1995). While the first climate models used sulfate aerosols as a surrogate for all anthropogenic aerosols, lately climate models have started to consider the major global aerosol components, sulfate, particulate organic matter, black carbon, sea salt and mineral dust. However, this has not led to a smaller uncertainty range of the indirect aerosol effect, because considering different aerosol species also introduces new uncertainties.

Estimates of the global annual mean cloud albedo enhancement due to the more and smaller cloud droplets for a given cloud water content (cloud albedo effect, (Twomey, 1977)) range between -0.3 to $-1.8 \mathrm{~W} \mathrm{~m}^{-2}$ (Forster et al., 2007), while the prolongation of cloud lifetime due to the reduction in drizzle production of the smaller cloud droplets (the so-called cloud lifetime effect, (Albrecht, 1989)) ranges between -0.3 and $-1.4 \mathrm{~W} \mathrm{~m}^{-2}$ (Lohmann and Feichter, 2005).

The indirect aerosol effects are larger than estimates of the direct and semi-direct effect. In a model intercomparison of nine different global models, the ensemble model average direct aerosol effect under all-sky conditions amounted to $-0.22 \mathrm{~W} \mathrm{~m}^{-2}$ in the annual global mean, ranging from +0.04 to $-0.41 \mathrm{~W} \mathrm{~m}^{-2}$ (Schulz et al., 2006). The semi-direct effect refers to temperature changes due to absorbing aerosols that can cause evaporation of cloud droplets, as was shown in a large eddy model simulation study that used black carbon concentrations measured during the Indian Ocean Experiment (Ackerman et al., 2000). It ranges from 0.1 to $-0.5 \mathrm{~W} \mathrm{~m}^{-2}$ in global simulations (Lohmann and Feichter, 2005). The semi-direct effect can result in a cooling depending on the location of the black carbon with respect to the cloud (Penner et al., 2003).

Published by Copernicus Publications on behalf of the European Geosciences Union. 
Table 1. Sensitivity Simulations.

\begin{tabular}{|c|c|}
\hline Simulation & Description \\
\hline ECHAM5-RH & $\begin{array}{l}\text { Simulation with ECHAM5-HAM coupled to the double-moment cloud microphysics } \\
\text { scheme using the (Sundqvist et al., 1989) cloud cover parameterization that only depends } \\
\text { on relative humidity }\end{array}$ \\
\hline ECHAM5-COV & As ECHAM5-RH, but using the (Tompkins, 2002) cloud cover parameterization \\
\hline ECHAM5-REF & $\begin{array}{l}\text { Reference simulation with the standard cloud physics scheme, that only predicts the } \\
\text { cloud water and cloud ice mixing ratios but not their number concentrations and uses the } \\
\text { (Sundqvist et al., 1989) cloud cover parameterization. It also contains ECHAM5-HAM but } \\
\text { ECHAM5-HAM is not coupled to the cloud scheme. }\end{array}$ \\
\hline ECHAM5-1985 & As ECHAM5-RH, but using the aerosol emissions that were used in ECHAM4 \\
\hline ECHAM4 & Simulation with ECHAM4 (Lohmann and Diehl, 2006) \\
\hline
\end{tabular}

Aerosols can also affect ice clouds, however, these indirect aerosol effects are even more uncertain. Global climate model studies suggest that if, in addition to mineral dust, hydrophilic black carbon aerosols are assumed to act as ice nuclei at temperatures between 0 and $-35^{\circ} \mathrm{C}$, then increases in aerosol concentration from pre-industrial to present times may cause a glaciation indirect effect (Lohmann, 2002a). The glaciation effect refers to an increase in ice nuclei that results in a more frequent glaciation of supercooled stratiform clouds and increases the amount of precipitation via the ice phase. This decreases the global mean cloud cover and allows more solar radiation to be absorbed in the atmosphere. Whether or not the glaciation effect can partly offset the warm indirect aerosol effect depends on the competition between the ice nucleating abilities of the natural and anthropogenic freezing nuclei (Lohmann and Diehl, 2006).

Previous estimates of indirect aerosol effects with the global climate model ECHAM4 were conducted by predicting only the mass mixing ratios of the different aerosol species. The aerosol number concentration was obtained from prescribed log-normal distributions for each aerosol compound, assuming an external aerosol mixture. Recently, size-segregated, interactive multi-component aerosol modules have been embedded into global models allowing to simulate the mixing state explicitly (see (Stier et al., 2005) for a review). However, the coupling between size-segregated, interactive multi-component aerosol modules with double moment cloud microphysics schemes that consider aerosol effects on water and mixed-phase clouds, has just begun.

In this paper we investigate the impact of the microphysical aerosol scheme ECHAM5-HAM (Stier et al., 2005) together with different aerosol emissions on aerosol and cloud properties in the present-day climate and for estimates of the total anthropogenic aerosol effect. ECHAM5-HAM predicts the aerosol mixing state in addition to the aerosol mass and number concentrations. Here it is coupled to the doublemoment cloud microphysics scheme (Lohmann et al., 1999; Lohmann, 2002b; Lohmann and Diehl, 2006).
We focus only on those differences between ECHAM4 and ECHAM5 that are related to the different treatment of aerosols and cloud microphysics as a detailed comparison of these model versions is beyond the scope of this paper. The questions to be answered are:

- What is the impact of the revised parameterization of the Bergeron-Findeisen process on the simulated liquid water versus ice distribution in mixed-phase clouds?

- What is the impact of different aerosol emissions on the simulated anthropogenic aerosol effect?

- What is the impact of the cloud cover scheme on the simulated anthropogenic aerosol effect?

\section{Model description and set-up of the simulations}

We use the new version of the Hamburg general circulation model (GCM) ECHAM5 (Roeckner et al., 2003). As compared to the standard ECHAM4 (Roeckner et al., 1996), it now includes operationally prognostic equations for the mass mixing ratios of cloud liquid water and ice (Lohmann and Roeckner, 1996). For the simulations discussed here, additional prognostic equations of the number concentrations of cloud droplets and ice crystals following their implementation in sensitivity studies with ECHAM4 (Lohmann et al., 1999; Lohmann, 2002b; Lohmann and Diehl, 2006) have also been introduced. ECHAM5 includes a new radiation scheme with 16 bands in the longwave regime (Mlawer et al., 1997). The shortwave code is essentially unchanged except that the number of spectral intervals is four instead of two in ECHAM4. However, in this study a six-band version of the code has been applied with two additional bands in the visible and ultraviolet (Cagnazzo et al., 2007). ECHAM5 also includes a new mass and shape-preserving advection scheme (Lin and Rood, 1996).

We compare different simulations with ECHAM5 as summarized in Table 1. These simulations are conducted in order to understand the importance of the double-moment cloud 
microphysics scheme including the revised parameterization of the Bergeron-Findeisen process on the present-day climate and to evaluate the impact of the cloud cover scheme and the biomass burning emissions for the anthropogenic aerosol effect.

\subsection{Aerosols}

The double-moment modal aerosol microphysics scheme HAM (Stier et al., 2005) has been included in ECHAM5 (simulation ECHAM5-REF). It predicts the evolution of an ensemble of microphysically interacting internally- and externally-mixed aerosol populations as well as their size distribution and composition. The size distribution is represented by a superposition of log-normal modes including the major global aerosol compounds sulfate, black carbon, particulate organic matter, sea salt and mineral dust (Stier et al., 2005). With the prognostic treatment of the mixing state it is possible to maintain an external mixture of hydrophobic particles that become aged to the hydrophilic/mixed modes by the condensation of sulfuric acid and the coagulation with hydrophilic modes. The e-folding ageing timescale for the hydrophobic to hydrophilic black carbon is 0.7 days (Stier et al., 2006).

The aerosol radiative properties of ECHAM5-HAM are calculated in the framework of Mie theory (see (Stier et al., 2005, 2007)). For each aerosol mode, effective refractive indices are calculated by volume-averaging the refractive indices of all components, including the prognostic aerosol water. The effective complex refractive indices and the Mie size-parameters for each mode serve as input to look-up tables for the aerosol radiative properties, providing extinction cross-section, single scattering albedo, and asymmetry parameter to the ECHAM5 radiation scheme.

While HAM does not interact with the cloud scheme in ECHAM5-REF, in the remaining simulations it is coupled to the cloud scheme as follows. Cloud droplet nucleation $Q_{\text {nucl }}$ $\left[\mathrm{m}^{-3} \mathrm{~s}^{-1}\right]$ is parameterized according to (Lin and Leaitch, 1997):

$Q_{\text {nucl }}=\max \left[\frac{1}{\Delta t}\left(0.1\left(\frac{N_{a} w}{w+\alpha N_{a}}\right)^{1.27}-N_{l, \text { old }}\right), 0\right]$

where $N_{a}=$ number concentration of the aerosol particles with wet radi $>0.035 \mu \mathrm{m}\left[\mathrm{m}^{-3}\right], w=$ vertical velocity $\left[\mathrm{ms}^{-1}\right]$, $\Delta t=$ time step, $N_{l, \text { old }}$ is the cloud droplet number concentration from the previous timestep and $\alpha=0.023 \mathrm{~cm}^{4} \mathrm{~s}^{-1}$ is obtained from observations (Lin and Leaitch, 1997). This simplified assumption is justified because aerosol size dominates aerosol activation in the first instance (Dusek et al., 2006). Moreover, all aerosols that have been in the atmosphere longer than a few hours acquire enough soluble material to participate in cloud droplet nucleation (Dusek et al., 2006). The cut-off radius of $0.035 \mu \mathrm{m}$ falls in-between the activation radii observed for maritime and continental aerosols by (Dusek et al., 2006).
The updraft velocity $w$ is obtained as the sum of the grid mean vertical velocity $\bar{w}$ and a turbulent contribution expressed in terms of the turbulent kinetic energy (TKE) for stratiform clouds (Lohmann et al., 1999). TKE in turn is obtained from a prognostic equation described in (Brinkop and Roeckner, 1995). For stratiform clouds originating from detrainment of convective clouds also a contribution of the convectively available potential energy (CAPE) (Rogers and Yau, 1989) has been added:

$w= \begin{cases}\bar{w}+1.33 \sqrt{\mathrm{TKE}} & \text { stratiform clouds } \\ \bar{w}+\sqrt{\mathrm{CAPE}}+1.33 \sqrt{\mathrm{TKE}} & \text { convective clouds }\end{cases}$

In accordance with typical observed ranges for stratocumulus (Quante, 2004), the lower bound on the cloud droplet number concentration whenever a cloud is present is set to $40 \mathrm{~cm}^{-3}$ in all simulations (ECHAM4, and the ECHAM5 simulations with the double-moment cloud microphysics scheme).

Note that the aerosol scheme in ECHAM4 was much simpler. It only predicts aerosol mass mixing ratios and assumes an external aerosol mixture (Lohmann et al., 1999). There all accumulation and coarse mode sea salt and dust particles, accumulation size sulfate aerosols and hydrophilic black and organic carbon were available for nucleation.

In the ECHAM5 simulations the AeroCom B year 2000 emissions from (Dentener et al., 2006) are used. In order to reduce the differences between the anthropogenic emissions in ECHAM5-HAM and in ECHAM4, we conduct one simulation with ECHAM5-HAM in which we use the anthropogenic emissions from the 1985 emission inventory that was used for the ECHAM4 simulations (simulation ECHAM51985). The main difference between the 2000 emission inventory and the 1985 emission inventory is the methodology of obtaining biomass burning emissions. Whereas the global mean black and organic carbon emissions amount to 11.7 and $105 \mathrm{Tg} \mathrm{C} \mathrm{yr}^{-1}$ in ECHAM4 using the 1985 emission inventory (Liousse et al., 1996), they only amount to 7.7 and 47.4 $\mathrm{Tg} \mathrm{C} \mathrm{yr}^{-1}$ in the 2000 emission inventory (Dentener et al., 2006). The global mean sulfur emissions are comparable amounting to $95.5 \mathrm{Tg} \mathrm{Syr}^{-1}$ in the 1985 emission inventory and to $94.6 \mathrm{Tg} \mathrm{S} \mathrm{yr}^{-1}$ in 2000 . However, the anthropogenic component is larger in the 1985 emission inventory amounting to $69.3 \mathrm{Tg} \mathrm{S} \mathrm{yr}^{-1}$ instead of $56.3 \mathrm{Tg} \mathrm{S} \mathrm{yr}^{-1}$ in 2000. Differences remain for the natural emissions. Mineral dust emissions are calculated online in ECHAM5HAM (Stier et al., 2005) but are prescribed in ECHAM4 (Lohmann et al., 1999). Sea salt is calculated online in both ECHAM4 and ECHAM5-HAM. While the parameterization from (Monahan et al., 1986) was used in ECHAM4, a merged parameterization from (Monahan et al., 1986) and (Smith and Harrison, 1998) is used in ECHAM5-HAM (Stier et al., 2005). 


\subsection{Cloud microphysics}

The cloud scheme in ECHAM5 that is used for these studies includes the double-moment cloud microphysics scheme for cloud droplets and ice crystals that has been described in (Lohmann et al., 1999) and (Lohmann, 2002b).

In the standard experiment ECHAM5-RH we use the same fractional cloud cover scheme that has been used in ECHAM4. It diagnoses fractional cloud cover from relative humidity once a critical relative humidity is reached (Sundqvist et al., 1989). ECHAM5 has the option to include a prognostic statistical cloud cover scheme (Tompkins, 2002). It is based on a parameterization for the horizontal subgrid-scale variability of water vapor and cloud condensate, which is used to diagnose cloud fraction. This scheme considers that processes, such as deep convection, turbulence, and microphysics, directly affect the higher-order moments of the total water distribution, and thus, have an impact on cloud cover. We investigate the impact of the Tompkins cloud cover scheme in simulation ECHAM5-COV.

The autoconversion rate of cloud droplets to form raindrops is important for the cloud lifetime effect. Here we use the autoconversion rate $Q_{\text {aut }}\left[\mathrm{kg} \mathrm{kg}^{-1} \mathrm{~s}^{-1}\right]$ developed by (Khairoutdinov and Kogan, 2000):

$Q_{\text {aut }}=1350 \times q_{l}^{2.47} N_{l}^{-1.79}$

where $q_{l}$ is the cloud liquid water mass mixing ratio in $\mathrm{kg} \mathrm{kg}^{-1}$ and $N_{l}$ is the cloud droplet number concentration in $\mathrm{cm}^{-3}$.

Heterogeneous freezing in large-scale mixed-phase clouds considers immersion freezing and contact freezing by dust and soot aerosols and includes the size dependent aerosol diffusivity in the collision efficiency as described in (Lohmann and Diehl, 2006). Dust nuclei in both the ECHAM4 and ECHAM5 double-moment simulations are considered to have ice nucleating properties as deduced from laboratory studies for montmorillonite. Montmorillonite initiates contact and immersion freezing at rather high temperatures so that freezing by black carbon is less important and the glaciation indirect effect is negligible (Lohmann and Diehl, 2006). Black carbon and dust in internally mixed particles are involved in immersion freezing, whereas the externally mixed black carbon and dust aerosols participate in contact freezing in ECHAM5. This is an improvement over ECHAM4 where this distinction was not possible.

At subfreezing temperatures the vapor pressure over ice is lower than over water. This causes ice crystals in mixed-phase clouds to grow at the expense of cloud droplets (Bergeron-Findeisen process). The BergeronFindeisen process is parameterized such that a supercooled water cloud will glaciate once a threshold ice water content $\left(\mathrm{IWC}_{\text {crit }}=0.5 \mathrm{mg} \mathrm{kg}^{-1}\right)$ is exceeded. Before $\mathrm{IWC}_{\text {crit }}=0.5 \mathrm{mg} \mathrm{kg}^{-1}$ is reached, saturation with respect to water is assumed in accordance with observations by (Korolev and Isaac, 2006). Once this threshold is exceeded, the remaining liquid water will be forced to evaporate and be deposited onto the existing ice crystals within that timestep and saturation with respect to ice is assumed. This differs from ECHAM4 and from the operational version of ECHAM5 (ECHAM5-REF) where the remaining cloud water is not evaporated. There the remaining cloud droplets have to either freeze or grow to rain drops in subsequent time steps.

ECHAM4 includes a parameterization scheme for homogeneous freezing in cirrus clouds and allows supersaturation with respect to ice at temperatures below $-35^{\circ} \mathrm{C}$ (Kärcher and Lohmann, 2002; Lohmann and Kärcher, 2002). While a heterogeneous ice nucleation scenario in isolation would be available, we refrain from using that because homogeneous freezing is the overall more realistic scenario for cirrus formation (Lohmann et al., 2004). A parameterization that couples homogeneously frozen ice crystals and heterogeneously nucleated crystals has been developed (Kärcher et al., 2006) and will be implemented in ECHAM in the future. Until that is available, we limit ourselves to homogeneous freezing in ECHAM5.

\subsection{Cloud optical properties}

Cloud optical properties are formulated in terms of the cloud liquid and ice mass mixing ratios and their effective radii. Both in ECHAM4 and in the ECHAM5 simulations with the double-moment cloud microphysics scheme, the effective radius for cloud droplets is obtained from the mean volume radius and a simple parameterization of the dispersion effect that depends on the cloud droplet number concentration (Peng and Lohmann, 2003).

The effective ice crystal radius $r_{i e}$ that is appropriate for ice cloud optical properties is not easy to obtain from insitu observations because not all measurements of small ice crystals are yet reliable (Field et al., 2003). Thus, parameterizations that relate ice crystal size to ice water content or temperature yield vastly different results. In ECHAM5, $r_{i e}$ is empirically related to the ice water content (Lohmann and Roeckner, 1995):

$r_{i e}=83.8 \times \mathrm{IWC}^{0.216}$

where IWC is given in $\mathrm{g} \mathrm{m}^{-3}$ and $r_{i e}$ in $\mu \mathrm{m}$.

In ECHAM4 an empirical relationship between the mean volume radius $r_{v}$ and the effective radius (Moss, pers. comm. and (Lohmann, 2002b)) has been used:

$r_{i}=1.61 r_{v}^{3}+3.56 \times 10^{-4} r_{v}^{6}$

where $r_{v}$ is obtained from the cloud ice mixing ratio in the cloudy part of the grid box $q_{i}$ and the ice crystal number concentration $N_{i}$ :

$r_{v}=\left(\frac{3 q_{i} \rho_{a}}{4 \pi \rho_{i} N_{i}}\right)^{1 / 3}$

where $\rho_{a}=$ air density and $\rho_{i}=$ ice density $\left(500 \mathrm{~kg} \mathrm{~m}^{-3}\right)$. 
Table 2. Annual global mean cloud and aerosol properties and TOA energy budget. Aerosol optical depth (AOD) is obtained from different observations (Kinne, $2007^{1}$ ). The liquid water path (LWP) observations stem from SSM/I (Ferraro et al., 1996; Greenwald et al., 1993; Weng and Grody, 1994), and ISCCP and are restricted to oceans. Ice water path (IWP) has been derived from ISCCP data (Storelvmo et al., 2007) and includes data from land and oceans. Water vapor mass (WVM) data stem from MODIS. $N_{d}$ and $N_{i}$ refer to the vertically integrated cloud droplet and ice crystal number concentration, and $r_{\text {eff }}$ refers to the cloud top effective radius. Observations of $N_{d}$ and $r_{\text {eff }}$ are obtained from ISCCP (Han et al., 1998, 1994) and are limited to $50^{\circ} \mathrm{N}$ to $50^{\circ} \mathrm{S}$. Total precipitation $\left(P_{\text {tot }}\right)$ is taken from the Global Precipitation Data Set; total cloud cover (TCC) is obtained from surface observations (Hahn et al., 1994), ISCCP (Rossow and Schiffer, 1999) and MODIS data (King et al., 2003). The shortwave (SCF) and longwave cloud forcing (LCF) estimates are taken from (Kiehl and Trenberth, 1997). In addition estimates of LCF from TOVS retrievals (Susskind et al., 1997; Scott et al., 1999) are included. $r_{\text {eff }}$ was not diagnosed in ECHAM4 and no estimates of $N_{d}$ and $N_{i}$ are available from ECHAM5-REF.

\begin{tabular}{|c|c|c|c|c|c|c|}
\hline Simulation & ECHAM5-RH & ECHAM5-COV & ECHAM5-REF & ECHAM5-1985 & ECHAM4 & OBS \\
\hline LWP, $\mathrm{g} \mathrm{m}^{-2}$ & 64.6 & 63.6 & 57.2 & 68. & 80.6 & $50-84$ \\
\hline IWP, $\mathrm{g} \mathrm{m}^{-2}$ & 27.7 & 26.3 & 19.7 & 27.8 & 8.1 & 26.7 \\
\hline $\mathrm{N}_{d}, 10^{10} \mathrm{~m}^{-2}$ & 4.3 & 5.6 & & 7.3 & 19.7 & 4 \\
\hline $\mathrm{N}_{i}, 10^{10} \mathrm{~m}^{-2}$ & 0.7 & 0.7 & & 0.7 & 0.1 & \\
\hline$r_{\mathrm{eff}}, \mu \mathrm{m}$ & 10.5 & 9.9 & & 10.4 & & 11.4 \\
\hline WVM, $\mathrm{kg} \mathrm{m}^{-2}$ & 26.0 & 25.9 & 25.5 & 25.9 & 26.3 & 25.1 \\
\hline TCC, $\%$ & 62.5 & 63.8 & 63.6 & 63.0 & 67.6 & $62-67$ \\
\hline$P_{\text {tot }}, \mathrm{mm} \mathrm{d}^{-1}$ & 2.89 & 2.89 & 2.88 & 2.87 & 2.65 & 2.74 \\
\hline$P_{\text {strat }}, \mathrm{mm} \mathrm{d}^{-1}$ & 1.07 & 1.12 & 1.05 & 1.06 & 1.2 & \\
\hline$P_{\text {conv }}, \mathrm{mm} \mathrm{d}^{-1}$ & 1.82 & 1.77 & 1.82 & 1.81 & 1.45 & \\
\hline $\mathrm{SCF}, \mathrm{W} \mathrm{m}^{-2}$ & -52.4 & -50.6 & -55.5 & -53.7 & -46.4 & -50 \\
\hline $\mathrm{LCF}, \mathrm{W} \mathrm{m}^{-2}$ & 29.2 & 28.9 & 29.5 & 29.3 & 30.8 & $22-30$ \\
\hline AOD & 0.176 & 0.164 & 0.164 & 0.176 & 0.06 & $0.15-0.19$ \\
\hline
\end{tabular}

${ }^{1}$ Kinne, S.: Aerosol Direct Radiative Forcing with an AERONET touch, Atmos. Environ., submitted, 2007.

The use of Eq. (6), however, is problematic for optical properties of ice clouds in general because it assumes that the ice crystals are spherical. This assumption may be justified for newly formed ice crystals in cirrus clouds but is not supported by observations in mid-latitude ice clouds that are warmer than $-40^{\circ} \mathrm{C}$ (Korolev and Isaac, 2003). Using Eqs. (5) and (6) for the optical properties of all ice clouds yields considerably smaller ice crystals than using Eq. (4), which has a profound effect on the radiation balance. It results in a much larger longwave cloud forcing and too little outgoing longwave radiation. In order to re-adjust the radiation balance, the aggregation rate of ice crystals to form snow flakes needs to be artificially enhanced. This unrealistically reduces the ice water content as discussed below.

\subsection{Set-up of the simulations}

The ECHAM5 simulations have been carried out in T42 horizontal resolution $\left(2.8125^{\circ} \times 2.8125^{\circ}\right)$ and 19 vertical levels with the model top at $10 \mathrm{hPa}$ and a timestep of $30 \mathrm{~min}$. All simulations used climatological sea surface temperature and sea-ice extent. They were simulated for 5 years after an initial spin-up of 3 months using aerosol emissions for the year 2000. To isolate the anthropogenic effect, the simulations with the double-moment cloud microphysics scheme were repeated with aerosol emissions representative for the year
1750 (Dentener et al., 2006). There is no pre-industrial simulation for ECHAM5-REF because the aerosols in ECHAM5REF do not affect cloud properties and, hence, cause no aerosol indirect effect.

These simulations are compared to a simulation with ECHAM4 that uses the same double-moment cloud microphysics scheme except for the changes discussed above. The simulations with ECHAM4 were carried out over 10 years in T30 horizontal resolution with 19 vertical levels with present-day aerosol emissions representative for the year 1985.

\section{Model evaluation}

\subsection{Annual global means}

An overview of the global-mean radiation and water budgets is given in Table 2. The ECHAM5 simulations with the double-moment cloud microphysics scheme are conducted such that the global annual mean radiation budget is balanced to within $2 \mathrm{~W} \mathrm{~m}^{-2}$ at the top-of-the-atmosphere (TOA) and that the values of the shortwave and longwave cloud forcing are within the uncertainty of the radiative flux measurements of $\pm 5 \mathrm{~W} \mathrm{~m}^{-2}$ as reported by (Kiehl and Trenberth, 1997). 
Table 3. Annual global mean changes in aerosol optical depth, the TOA radiative budget and hydrological cycle from 1750 to present-day. Note that liquid water path changes here refer to the average over land and ocean. The cloud albedo effect for the ECHAM5 simulations has been calculated from the monthly mean average changes in the cloud droplet effective radius between 1750 and present-day.

\begin{tabular}{|c|c|c|c|c|}
\hline Simulation & ECHAM5-RH & ECHAM5-COV & ECHAM5-1985 & ECHAM4 \\
\hline Aerosol optical depth & 0.042 & 0.04 & 0.037 & 0.04 \\
\hline Liquid water path, $\mathrm{g} \mathrm{m}^{-2}$ & 6.9 & 9.2 & 14.2 & 12.7 \\
\hline Ice water path, $\mathrm{g} \mathrm{m}^{-2}$ & 0.0 & 0.2 & 0.4 & 0.1 \\
\hline$N_{d}, 10^{10} \mathrm{~m}^{-2}$ & 1.1 & 1.7 & 3.9 & 4.1 \\
\hline$N_{i}, 10^{10} \mathrm{~m}^{-2}$ & 0.01 & 0.02 & 0.03 & 0.03 \\
\hline Total cloud cover, $\%$ & 0.3 & 1.1 & 1.0 & 0.1 \\
\hline Total precipitation, $\mathrm{mm} \mathrm{d}^{-1}$ & -0.008 & -0.010 & -0.025 & -0.052 \\
\hline Cloud albedo effect, $\mathrm{W} \mathrm{m}^{-2}$ & -0.7 & -0.8 & -0.8 & \\
\hline Shortwave radiation, $\mathrm{W} \mathrm{m}^{-2}$ & -2.0 & -3.2 & -3.3 & -1.8 \\
\hline Longwave radiation, $\mathrm{W} \mathrm{m}^{-2}$ & 0.1 & 0.5 & 0.6 & 0.7 \\
\hline Net radiation, $\mathrm{W} \mathrm{m}^{-2}$ & -1.9 & -2.8 & -2.6 & -1.0 \\
\hline
\end{tabular}

Liquid water path cannot be retrieved reliably so that the satellite estimates vary substantially. They range between $50-84 \mathrm{~g} \mathrm{~m}^{-2}$ in the global annual mean over the oceans as deduced from various SSM/I data (Ferraro et al., 1996; Greenwald et al., 1993). All model simulations have values within this range. The global mean ice water path (land and ocean) as derived from the International Satellite Cloud Climatology Project (ISCCP) (Storelvmo et al., 2007) amounts to $26.7 \mathrm{~g} \mathrm{~m}^{-2}$. The ECHAM5 simulations with the doublemoment scheme agree very well with this estimate while the ice water path is underestimated in ECHAM4 and ECHAM5REF.

The vertically integrated cloud droplet number concentration was derived by (Han et al., 1998) from ISCCP data between $50^{\circ} \mathrm{S}$ and $50^{\circ} \mathrm{N}$ for 4 months (January, April, July, October) in 1987, the average of which can be considered as an annual mean. It amounts to $4 \times 10^{10} \mathrm{~m}^{-2}$ and is simulated best in ECHAM5-RH. The cloud top effective cloud droplet radii of warm clouds with cloud top temperatures above $0^{\circ} \mathrm{C}$ agree within $1.5 \mu \mathrm{m}$ with the observed ones derived from ISCCP data between $50^{\circ} \mathrm{S}$ and $50^{\circ} \mathrm{N}$ by (Han et al., 1994).

The vertically integrated ice crystal number concentration is rather similar in the ECHAM5 simulations. Due of the different approach to obtain the effective ice crystal radius in ECHAM4 that necessitates a smaller ice water path (see Sect. 2), its ice crystal number concentration amounts to only $15 \%$ of the concentrations in ECHAM5. Unfortunately there are no global observations of the ice crystal number concentrations.

The total cloud cover in ECHAM5-RH is smaller than in ECHAM4 due to enhanced convective precipitation as discussed below. It is at the high side of the satellite retrievals (Rossow and Schiffer, 1999) and surface observations (Hahn et al., 1994) in ECHAM4, but falls within the observational range in the ECHAM5 simulations. While precipitation was underestimated in ECHAM4 it is overestimated in all
ECHAM5 simulations due to more vigorous convection.

The cloud radiative forcing is defined as the difference in the all-sky shortwave or longwave minus the clear-sky shortwave or longwave radiation. The shortwave cloud forcing (SCF) has been estimated from ERBE satellites to amount to $-50 \mathrm{~W} \mathrm{~m}^{-2}$ and the longwave cloud forcing (LCF) to $30 \mathrm{~W} \mathrm{~m}^{-2}$ (Kiehl and Trenberth, 1997). However, LCF estimates from the TOVS satellites only amount to $22 \mathrm{~W} \mathrm{~m}^{-2}$ (Susskind et al., 1997; Scott et al., 1999), which provides an estimate of the measurement uncertainties. While SCF in ECHAM4 was underestimated with $-46.4 \mathrm{~W} \mathrm{~m}^{-2}$, it is up to $5.5 \mathrm{~W} \mathrm{~m}^{-2}$ larger than observed in the ECHAM5 simulations as a result of adjusting the model to match the global mean radiation balance at the top-of-the-atmosphere. On the contrary, the longwave cloud forcing is smaller in the ECHAM5 simulations than in ECHAM4. All ECHAM5 values fall between the ERBE and TOVS estimates of LCF (Table 2).

The aerosol optical depth from all ECHAM5 simulations fall within the observed uncertainty (see also (Stier et al., 2005)), whereas AOD is severely underpredicted in ECHAM4. As the anthropogenic aerosol optical depth is comparable in ECHAM4 and ECHAM5 (cf. Table 3), this points to a gross underestimate of the optical depth of natural aerosols in ECHAM4 (0.02 in ECHAM4 vs. about 0.13 in ECHAM5).

\subsection{Annual, zonal means}

Annual zonal means of the oceanic liquid water path, global ice water path, total cloud cover, precipitation, shortwave and longwave cloud forcing, aerosol optical depth, water vapor mass and vertically integrated number concentration of cloud droplet and ice crystals are shown in Figs. 1 and 2. The aerosol optical depth (AOD) is much smaller in ECHAM4 than in ECHAM5 and has a different latitudinal distribution than in both ECHAM5 and in the observations. The 

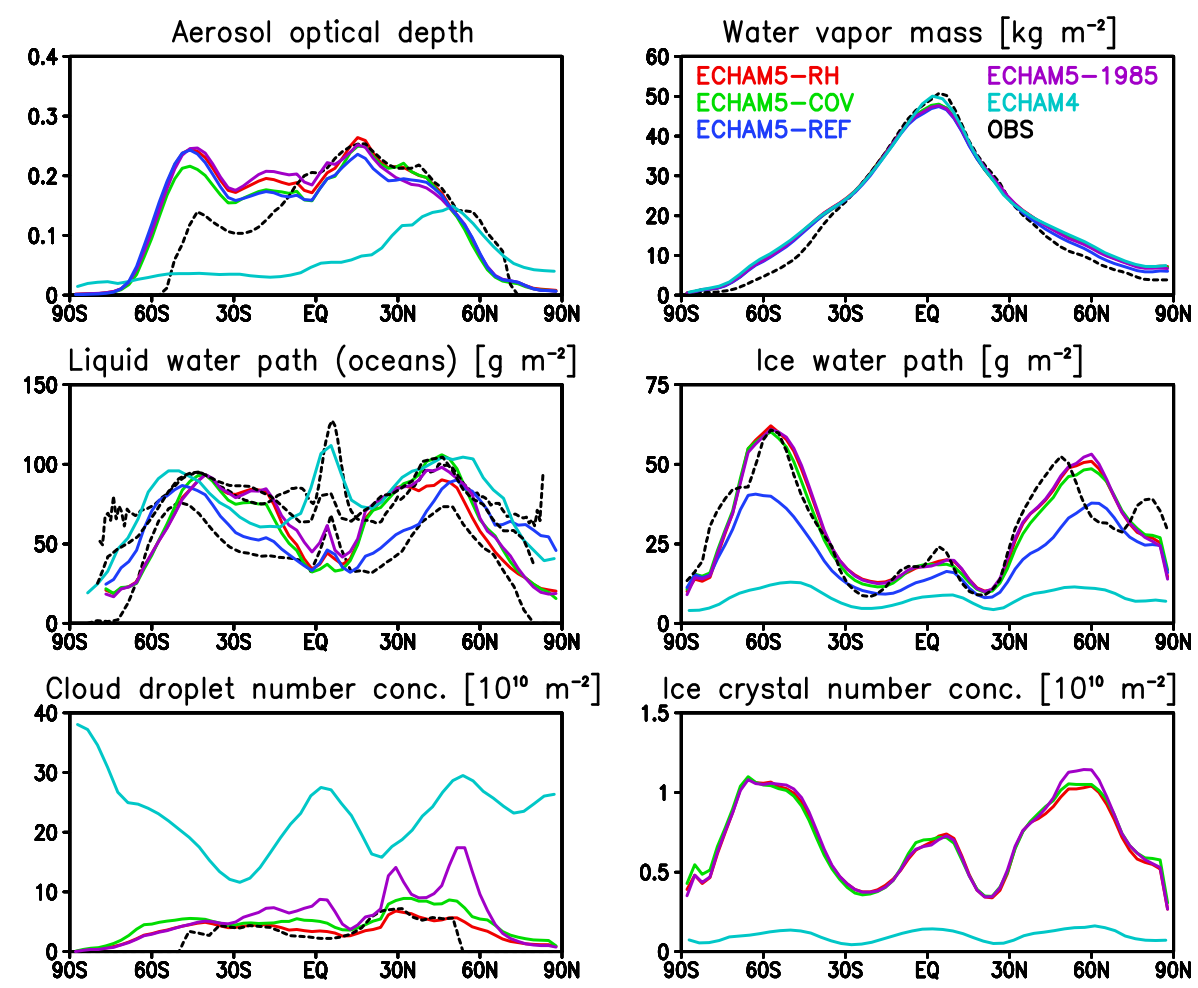

Fig. 1. Annual zonal means of the aerosol optical depth (AOD), water vapor mass (WVM), oceanic liquid water path (LWP), ice water path (IWP) and vertically integrated cloud droplet number concentration $\left(N_{c}\right)$ and ice crystal number concentration from different model simulations described in Table 1 and from observations described in Table 2. Dotted black lines refer to the combined MODIS-MISR retrieval for AOD, to MODIS data for WVM, to SSM/I data for LWP and to ISCCP data for IWP and $N_{c}$.
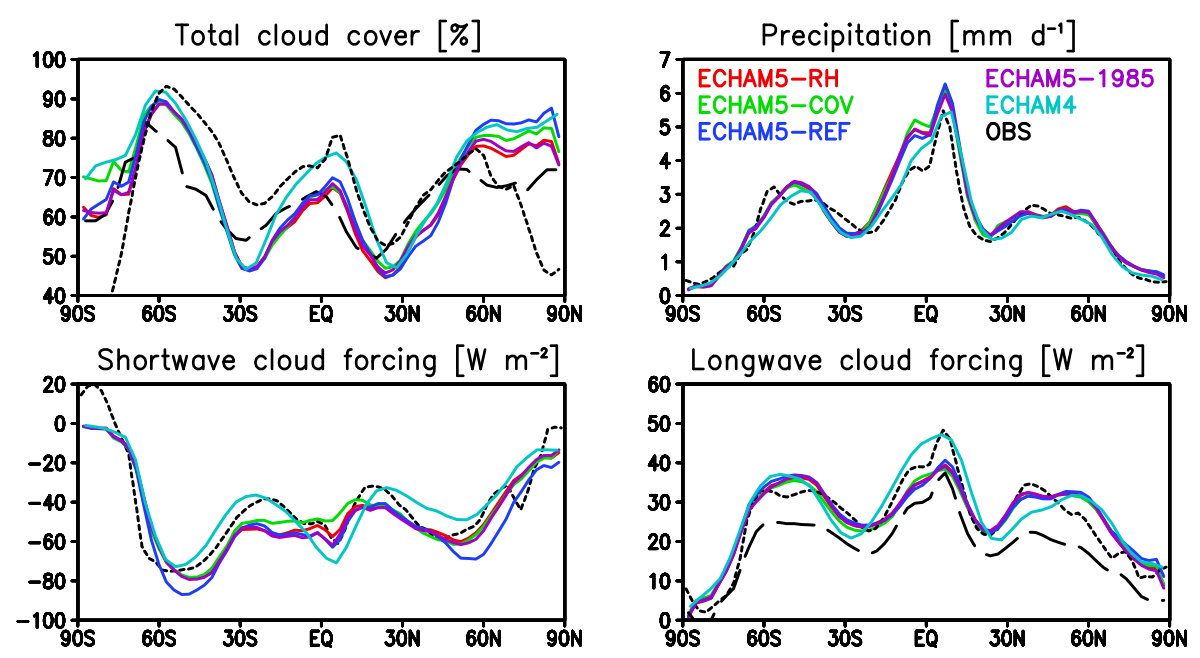

Fig. 2. As Fig. 1 but for total cloud cover, total precipitation, SCF and LCF. Dotted black lines refer to ISCCP data for cloud cover and to ERBE data for cloud forcing. Dashed lines refer to surface observations for total cloud cover and to TOVS data for LCF.

contribution of the natural aerosols sea salt and mineral dust is much larger in ECHAM5 than in ECHAM4 (cf. Tables 2 and 3 ). The reduced poleward transport in ECHAM5 results from the less diffuse new advection scheme for water vapor, cloud variables and aerosols employed in ECHAM5 (Roeckner et al., 2003). ECHAM5 predicts the meridional distribu- tion of AOD well, but overpredicts AOD over the Southern Ocean as compared to the combined MODIS-MISR AOD retrieval. In this combined AOD retrieved, MODIS data are employed over oceans and MISR data over land. AOD in ECHAM4 is much lower than observed everywhere but has hints of Arctic haze as suggested in the observations. 
There is, however, still some discrepancy between different aerosol optical depth estimates (Kinne, 2007 ${ }^{1}$ ) with the merged MODIS-MISR satellite estimate shown here being the best estimate.

The liquid water path distribution is also markedly different between ECHAM4 and ECHAM5. Whereas the liquid water path has its maximum in the tropics in ECHAM4, liquid water path is largest in the mid latitudes in all ECHAM5 simulations. The liquid water path in the different ECHAM5 simulations varies in magnitude, but its latitudinal pattern is similar. Outside the tropics it falls within the observational uncertainty range. In the mid-latitudes the liquid water path is higher in the ECHAM5 simulations with the doublemoment cloud microphysics scheme than in ECHAM5-REF due to aerosol-cloud coupling. Because the autoconversion rate depends inversely on the cloud droplet number concentration (Eq. 3), an increase in aerosol and, hence, cloud droplet number concentration prolongs the precipitation formation rate, leading to a higher liquid water path and a reduced removal of aerosols (see also (Lohmann and Feichter, 1997)).

The decrease in liquid water path in the tropics results from a larger convective precipitation efficiency in ECHAM5 than in ECHAM4. Even though the convection scheme has not changed from ECHAM4 to ECHAM5, the frequency of deep convection has increased in ECHAM5 because the longwave cooling rates are larger in the tropical upper troposphere with the introduction of the new longwave radiation scheme. Moreover, the increase from two wavelength bands in the shortwave radiation in ECHAM4 to six wavelength bands in ECHAM5 reduces the absorption of shortwave radiation in the atmosphere considerably (Wild and Roeckner, 2006). This enhanced cooling and reduced shortwave heating destabilizes the atmosphere causing more frequent deep convection events in ECHAM5. Thus, the global mean precipitation and especially the convective precipitation rate is systematically higher and the water vapor mass lower in ECHAM5 as compared to ECHAM4 (Table 2 and Figs. 1 and 2). In turn, tropical shallow convection occurs less often in ECHAM5 so that less cloud water is detrained from these clouds. Hence, the maximum in liquid water path in the tropics is reduced from ECHAM4 to ECHAM5. The ice water path is very well captured in the ECHAM5 double-moment scheme simulations, but underestimated in ECHAM5-REF and ECHAM4.

The vertically integrated cloud droplet number concentration agrees well with observations in the ECHAM5 doublemoment scheme simulations, but exceeds the observed concentration globally by a factor of 5 in ECHAM4 (cf. Table 2). Because the cloud droplet and ice crystal number concentrations are not predicted in ECHAM5-REF, they are absent from the figures and the table. When the 1985 aerosol emis-

\footnotetext{
${ }^{1}$ Kinne, S.: Aerosol Direct Radiative Forcing with an AERONET touch, Atmos. Environ., submitted, 2007.
}

sions are used, more cloud droplets than observed are simulated in the tropics and Northern Hemisphere midlatitudes. The higher cloud droplet number concentration in these regions reflects the higher carbonaceous aerosol emissions over Europe, south-east Asia and South and North America in the 1985 emission inventory.

The vertically integrated ice crystal number concentration is very similar in the ECHAM5 simulations with maxima in the tropics and in the midlatitudes. As mentioned above no global estimates are available of the ice crystal number concentration and even locally large uncertainties remain because of the difficulty with measuring small ice crystals (Field et al., 2003).

Because of the more vigorous precipitation and lower liquid water path in the tropics in the ECHAM5 simulations, the cloud cover, and the shortwave and longwave cloud forcing are also smaller in the tropics in the ECHAM5 simulations as compared to ECHAM4 (Fig. 2). Over mid-latitudes, where the liquid water path is generally larger in the ECHAM5 simulations as compared to ECHAM4, the shortwave cloud forcing is larger in the ECHAM5 simulations, in better agreement with the observations. The longwave cloud forcing in the ECHAM5 simulations in the tropics falls in between the longwave cloud forcing estimates from ERBE and from TOVS.

\subsection{Annual latitude-pressure cross sections}

In order to better understand the large differences between ECHAM4 and ECHAM5-RH, annual zonal mean plots of the aerosol number concentration $N_{a}$ available for droplet nucleation (with wet radii $>0.035 \mu \mathrm{m}$ ), liquid and ice water contents (LWC, IWC) of stratiform clouds, cloud droplet and ice crystal number concentrations, and cloud cover are shown as a function of altitude in Figs. 3 and 4. Most noticeable is the vastly different vertical distribution of the aerosol number concentration. In ECHAM4, the aerosol number concentration is higher in the boundary layer but smaller at higher altitudes than in ECHAM5-HAM. In ECHAM5-HAM secondary particles are formed in the upper free troposphere by nucleation, a pathway that is missing in ECHAM4. The upper free tropospheric new particle formation is a major contributor to the particle number, some of which subsequently grow to sizes larger than $0.035 \mu \mathrm{m}$ as seen in Fig. 3. In addition the 2000 emission inventory includes wildfires and biomass burning which are injected up to a height of $6 \mathrm{~km}$ (Dentener et al., 2006) whereas in the 1985 emission inventory used in ECHAM4, biomass burning emissions were only distributed over the first and second model level above the surface explaining the higher aerosol number concentrations in the boundary layer. Lastly, the scavenging of aerosols from convective clouds has changed between ECHAM4 and ECHAM5-HAM in which now mode specific semi-empirical scavenging coefficients are employed (Stier et al., 2005). 

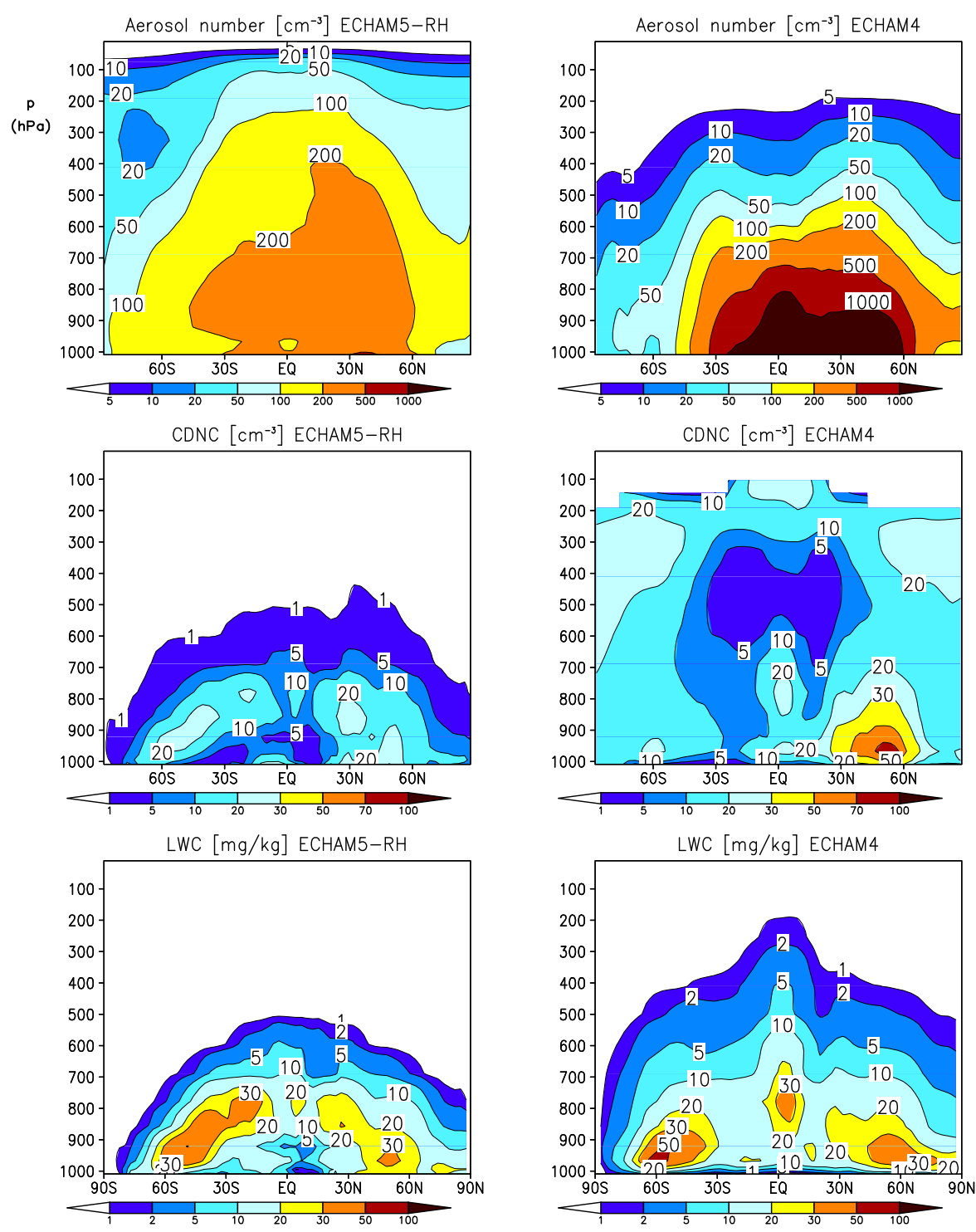

Fig. 3. Annual zonal mean latitude versus pressure plots of the aerosol number concentration with wet radii $>0.035 \mu$ m, the cloud droplet number concentration (CDNC) and the liquid water (LWC) from the simulation ECHAM5-RH and from ECHAM4. LWC and CDNC are averaged over the cloudy and clear part of the grid box and are sampled over clear and cloudy periods.

Despite higher aerosol concentrations in the mid and upper troposphere, the cloud droplet number concentration is almost everywhere lower in ECHAM5-RH. In the boundary layer this is consistent with the smaller aerosol number concentration. In the mid troposphere the cloud droplet number concentration has decreased in favor of the ice crystal number concentration as the Bergeron-Findeisen process is more efficient in ECHAM5-RH (Fig. 4). This is in better agreement with in-situ data as discussed in the next subsection. The cloud cover is smaller in ECHAM5-RH as compared to ECHAM4 especially in the upper troposphere due to the more vigorous convection in ECHAM5-RH.

\subsection{Comparison with field data}

There is a caveat when trying to validate climate model output with data from field experiments because a climate model cannot be expected to capture individual events. Nevertheless, they are the best observations available for the validation of aerosol and cloud properties within the atmosphere.

\subsubsection{Aerosols}

An in-depth comparison of aerosol mass and number concentrations in clean and polluted regions with observations is given in (Stier et al., 2005). Here we just show an example of an aerosol vertical profile comparison with data that have become available since then. 

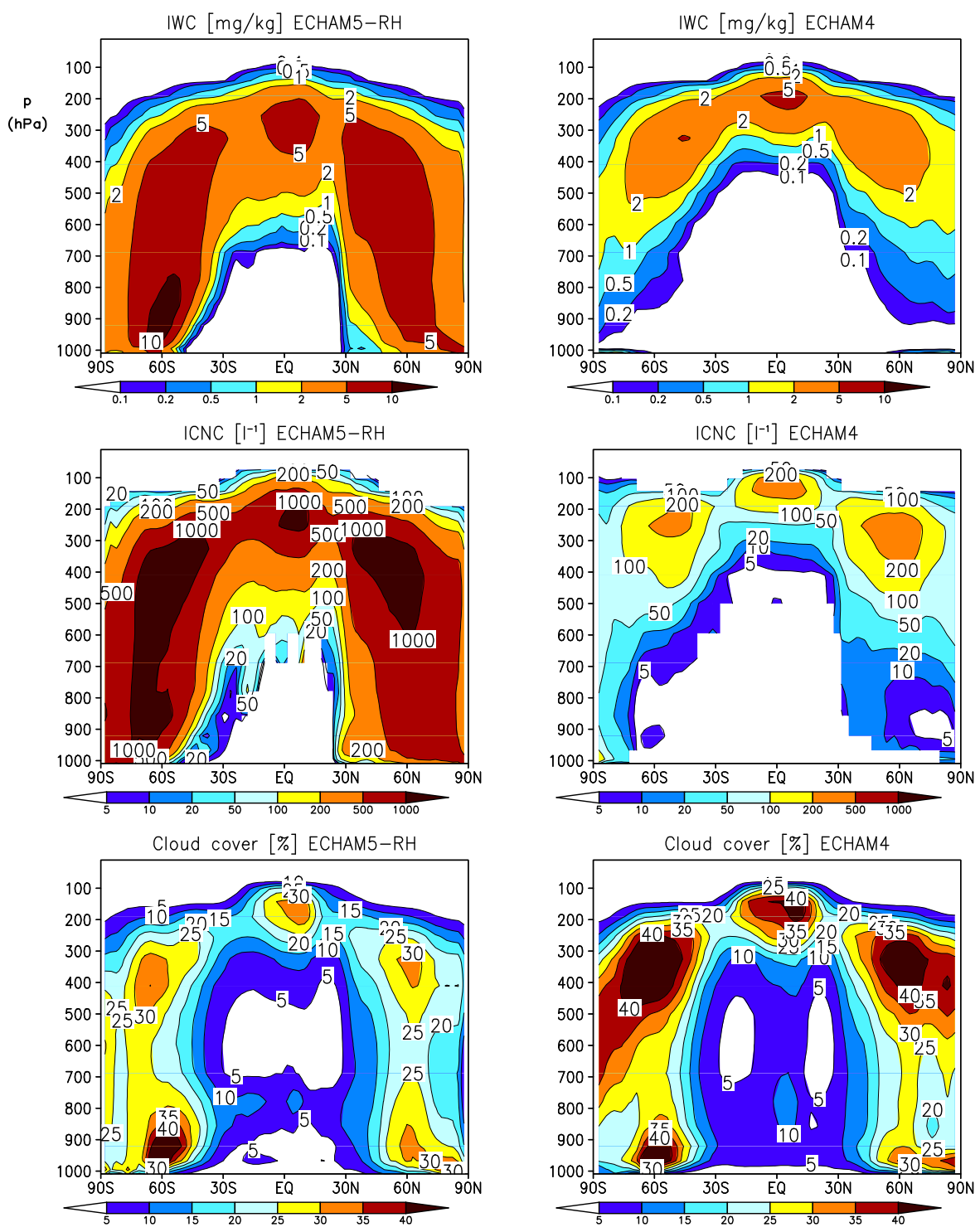

Fig. 4. As Fig. 3 but for the ice water content (IWC), ice crystal number concentration (ICNC), and cloud cover from the simulation ECHAM5-RH and from ECHAM4. IWC and ICNC are averaged over the cloudy and clear part of the grid box and are sampled over clear and cloudy periods.

Figure 5 shows observed vertical profiles plus error bars of the black carbon mass and the total aerosol mass from Houston, Texas (Schwarz et al., 2006) in November 2004. The thermal tropopause was observed to be near $150 \mathrm{hPa}$. We selected the same data plus their $25 \%$ and $75 \%$ percentiles from each November of the simulation in the region between 29$38^{\circ} \mathrm{N}$ and $88-98^{\circ} \mathrm{W}$ that encompasses the aircraft flights.

There is almost no difference in the total aerosol mass in all ECHAM5 simulations, which reproduce the observed vertical distribution well. The $25 \%$ and $75 \%$ percentiles of all simulations encompass the measurement uncertainty everywhere. In the mid troposphere, the aerosol concentrations in all ECHAM5 simulations are, however, on the high side.
This is probably due to deficiencies in wet scavenging which controls the aerosol concentrations in the free atmosphere.

ECHAM4 has a completely different vertical profile than ECHAM5. While the ECHAM4 25\% and 75\% percentiles encompass the observations below $400 \mathrm{hPa}$, the aerosol mass rapidly decreases with altitude and drastically underestimates the observations above $300 \mathrm{hPa}$. The improved representation of the upper troposphere aerosol concentration in ECHAM5 is indicative of the importance of aerosol nucleation and the subsequent microphysical growth included in the aerosol module HAM. Secondly, it is due to an improved vertical transport and aerosol removal scheme in ECHAM5. The larger aerosol concentrations in ECHAM4 

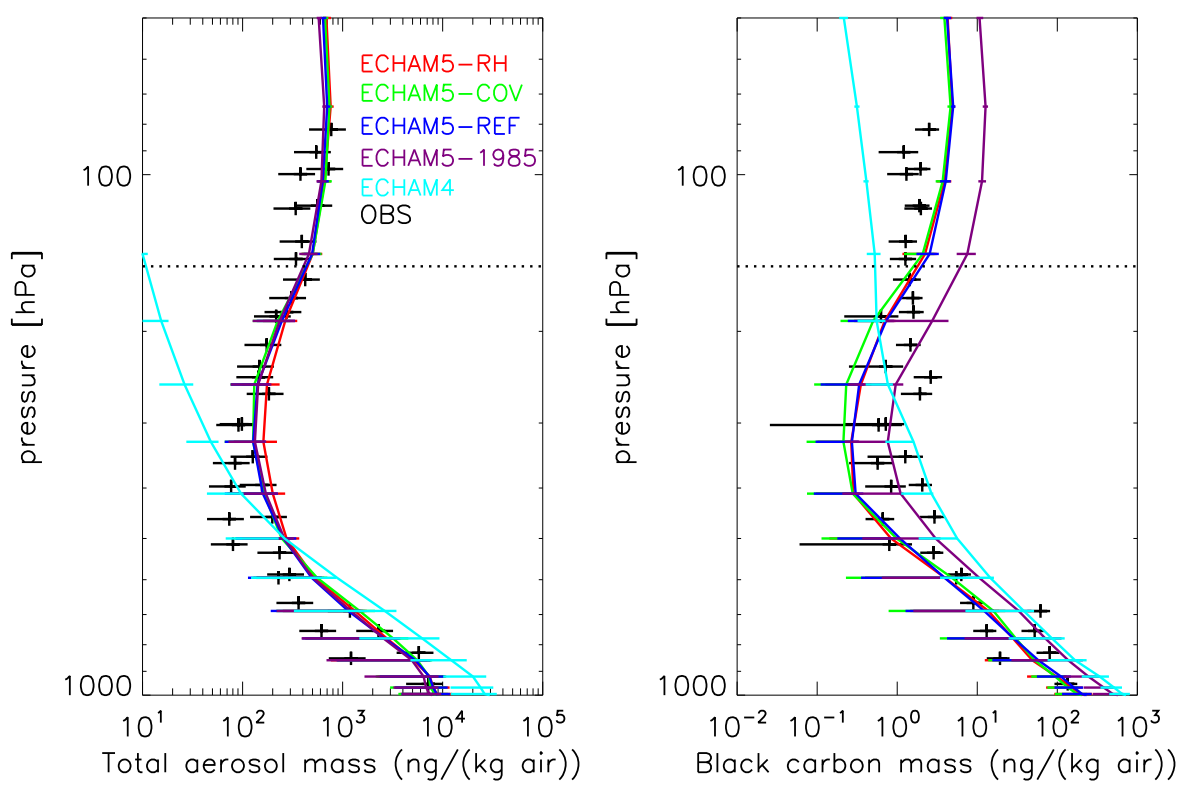

Fig. 5. Vertical profiles of the observed total aerosol mass plus error bars and the black carbon mass as obtained from flights out of Houston, Texas (Schwarz et al., 2006) in November 2004. The model results are shown as multi-year November averages for the geographic region between $29-38^{\circ} \mathrm{N}$ and $88-98^{\circ} \mathrm{W}$ that encompasses the aircraft flights. The model variability is identified with the $25 \%$ and $75 \%$ percentiles calculated from all 12-hourly mean concentrations obtained from the multi-year Novembers.

than in ECHAM5 below $500 \mathrm{hPa}$ stem from differences in emissions and removal rates.

In terms of the black carbon mass mixing ratio, there is hardly any difference between the simulations ECHAM5REF, ECHAM5-RH and ECHAM5-COV and they fall within the measurement uncertainty in the troposphere. The ECHAM5-1985 simulation has a higher black carbon mass mixing ratio because of its higher black carbon emissions. Again, ECHAM4 has a completely different vertical profile than all the ECHAM5 simulations with a higher black carbon mass below $200 \mathrm{hPa}$ and less black carbon aloft. The underestimation of black carbon in the stratosphere in ECHAM4 is less severe than for the total aerosol mass. This suggests that aerosol nucleation and subsequent growth and differences in the scavenging ratios are the likely reason with changes in transport playing a more minor role.

In the stratosphere, all ECHAM5 simulations overestimate the black carbon mass whereas the total aerosol mass is correctly simulated. This indicates that other aerosol species but black carbon are more efficiently removed from the atmosphere. The same relative behaviour can be noticed in ECHAM4, where the underprediction in black carbon mass in the stratosphere is less severe than for the total aerosol mass.

\subsubsection{Cloud properties}

In terms of the validation of cloud properties, we compare LWC, IWC and total water content (TWC) of stratiform clouds as a function of temperature between $0^{\circ} \mathrm{C}$ and $-35^{\circ} \mathrm{C}$ with stratiform cloud observations taken from different field projects over Canada in winter, spring and fall (Korolev et al., 2003). We took model data from one year in the same months (December-April, September/October) and the same region as the observations were taken.

In the observations, the distinction between ice and liquid is based on the ratio of IWC to TWC from separate measurements of the liquid and total water content with different sensors of the Nevzorov probe (Korolev et al., 1998). Clouds are considered liquid when the ratio IWC/TWC is less than $10 \%$ and ice, when the ratio IWC/TWC exceeds $90 \%$ (Korolev et al., 2003).

The temperature dependence of LWC, IWC and TWC for clouds with TWC $>0.003 \mathrm{~g} \mathrm{~m}^{-3}$ is shown in Fig. 6. Whereas the observed LWC increases from $0.017 \mathrm{~g} \mathrm{~m}^{-3}$ at $-33^{\circ} \mathrm{C}$ to $0.1 \mathrm{~g} \mathrm{~m}^{-3}$ at $-2^{\circ} \mathrm{C}$, the increase in IWC with temperature is more modest. The observed IWC has a weak maximum of $0.04 \mathrm{~g} \mathrm{~m}^{-3}$ at $\sim-12^{\circ} \mathrm{C}$ where depositional growth is most effective. At $-20^{\circ} \mathrm{C}$ a cross-over from more LWC at higher temperatures to more IWC at lower temperatures is observed.

While one needs to compare grid-average values of cloud water path with satellite data, for the comparison with in-situ measurements the in-cloud values of LWC, IWC and TWC, i.e. the water contents within the cloudy part of the grid box are used. The temperature dependencies of LWC, IWC and TWC are rather similar in the ECHAM5 simulations with the double moment cloud microphysics scheme. They mimic the observed modest change in IWC with temperature and the 

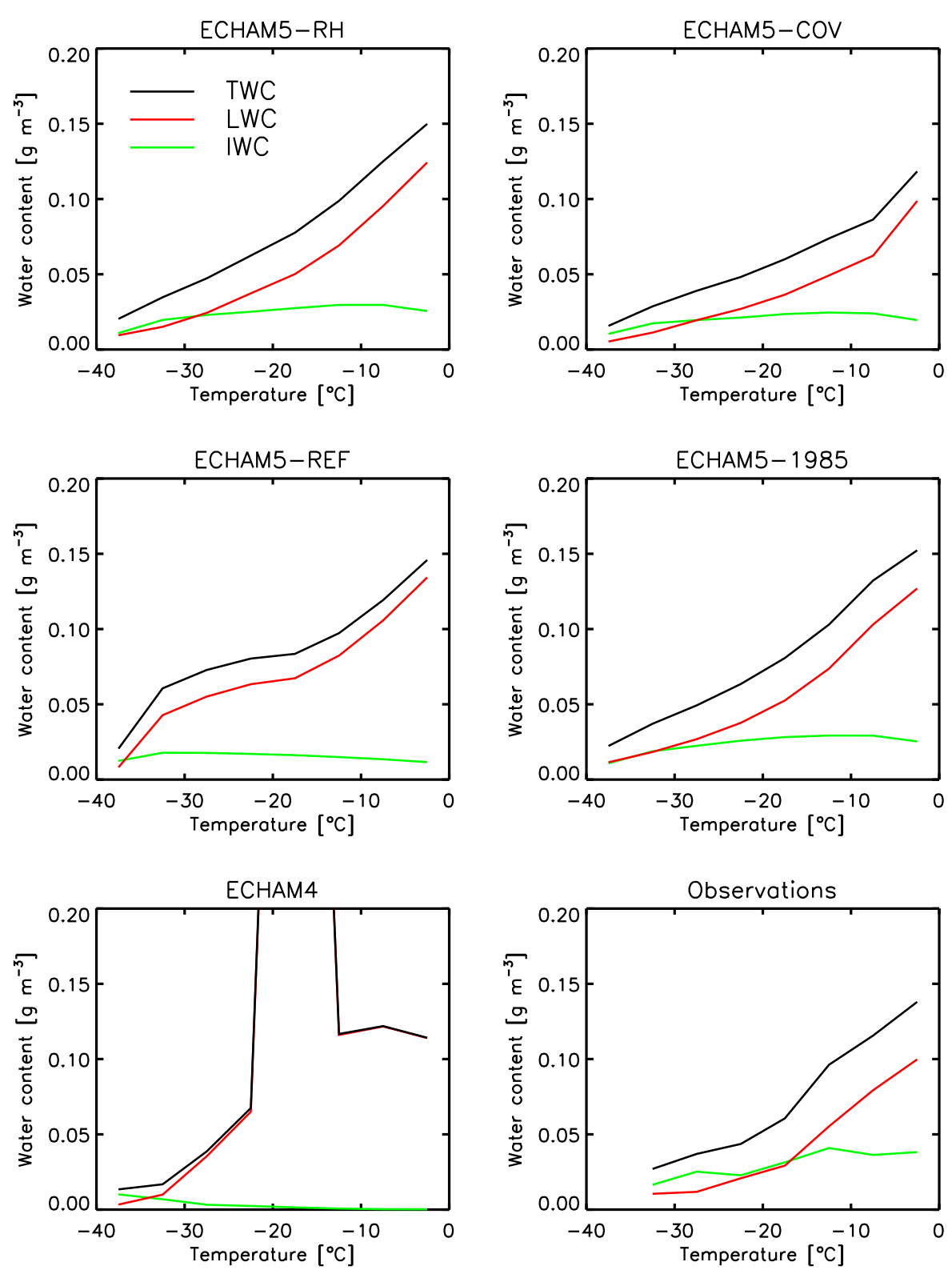

Fig. 6. In-cloud values of the liquid water content (LWC), ice water content (IWC) and the sum of both, the total water content (TWC), as a function of temperature from different model simulations as compared to observations from (Korolev et al., 2003).

steady increase in LWC and TWC with temperature, but the temperature at which LWC and IWC cross over is lower than observed. ECHAM5-REF overestimates LWC at the expense of IWC because of its less efficient Bergeron-Findeisen process (see Sect. 2).

The much lower IWC in ECHAM4 results from the less efficient Bergeron-Findeisen process and the enhanced aggregation rate that is necessary because of the smaller ice crystals (Eqs. 5 and 6 and Sect. 2.3). It depletes the ice water content as shown in Fig. 6. This suggests that it is better to use Eq. (4) which is the basis for all ECHAM5 simulations. As discussed above, Eq. (6) is problematic to use because it assumes that the ice crystals are spherical, which is not jus- tified in mid-latitude ice clouds that are warmer than $-40^{\circ} \mathrm{C}$ (Korolev and Isaac, 2003). LWC in ECHAM4 is highly overestimated between -15 and $-20^{\circ} \mathrm{C}$ with $0.8 \mathrm{~g} \mathrm{~m}^{-3}$ because of the inefficient Bergeron-Findeisen process.

The probability distributions of mixed-phase cloud composition for clouds with $\mathrm{TWC}>0.003 \mathrm{~g} \mathrm{~m}^{-3}$ for different temperature intervals is shown in Fig. 7. It is apparent from the observations that clouds tend to be composed of more than $90 \%$ of water or to more than $90 \%$ of ice due to the Bergeron-Findeisen process. The higher occurrence of IWC/TWC between 0.6 to 0.9 seems to be rather a measurement problem (A. Korolev, personal communication, 2006). As expected, the occurrence of a high percentage of ice is 

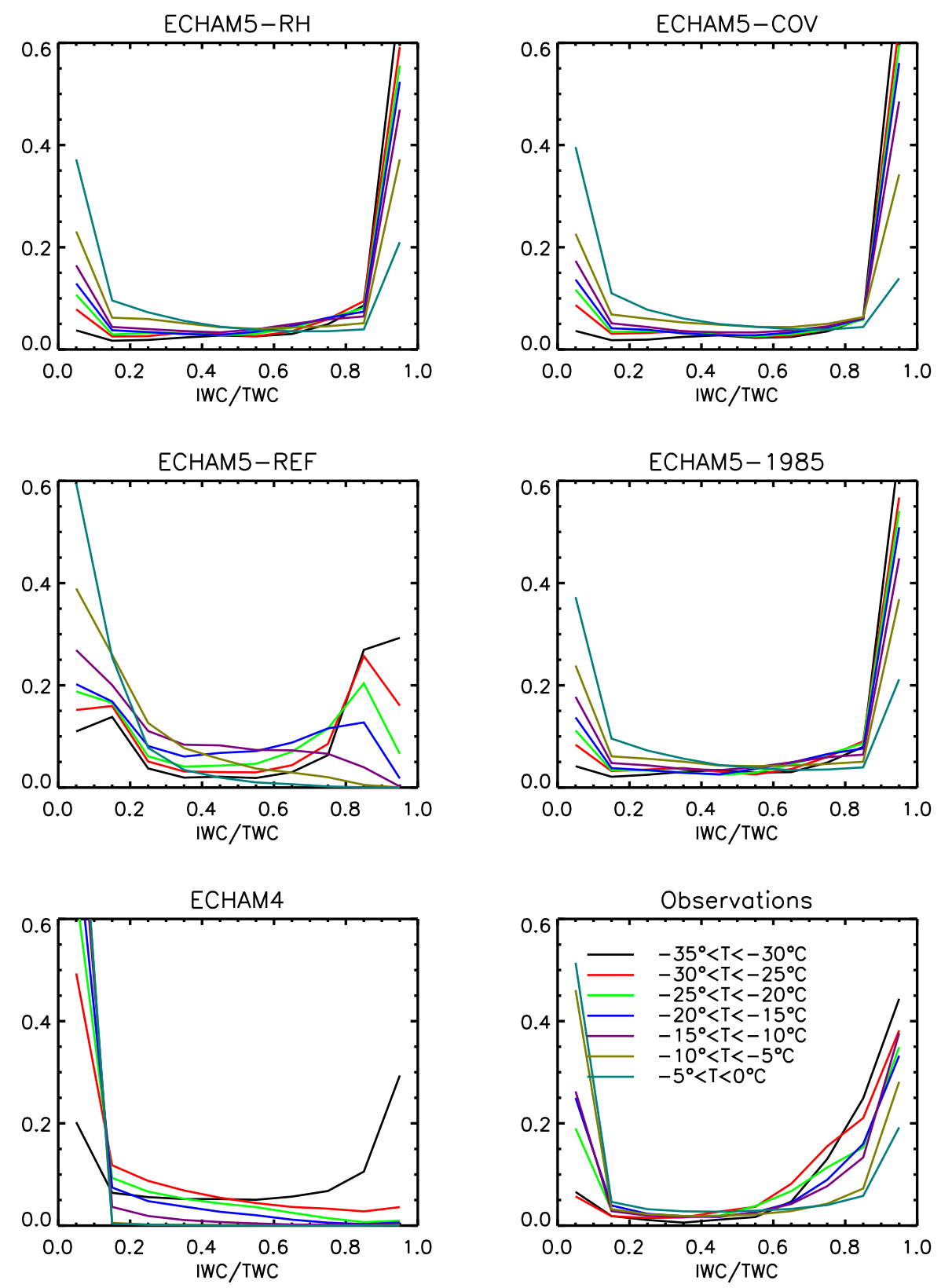

Fig. 7. Probability distributions of mixed-phase cloud composition (IWC/TWC) for different temperature intervals from different model simulations as compared to observations from (Korolev et al., 2003).

more likely at colder temperatures whereas at warmer temperatures clouds are mainly composed of water. While all ECHAM5 simulations with the double-moment cloud microphysics scheme overpredict the occurrence of almost pure ice clouds at colder temperatures, ECHAM4 underestimates high IWC, and both ECHAM4 and ECHAM5-REF overestimate the occurrence of almost pure water clouds due to their smaller ice water content.

The cloud droplet and ice crystal number concentrations with diameters between 5-95 $\mu \mathrm{m}$ are shown as a function of temperature in Fig. 8. The observations stem from the forward scattering spectrometer probe (FSSP) that traditionally measures cloud droplets, but has also been used to measure ice crystal number concentrations, even though it has some caveats (Korolev et al., 2003). The observations show the highest particle concentrations for a IWC/TWC ratio $<0.1$, which is indicative of almost pure water clouds. As the IWC/TWC ratio increases, fewer particles are observed especially in case of IWC/TWC $>0.9$, which is indicative of almost pure ice clouds. 

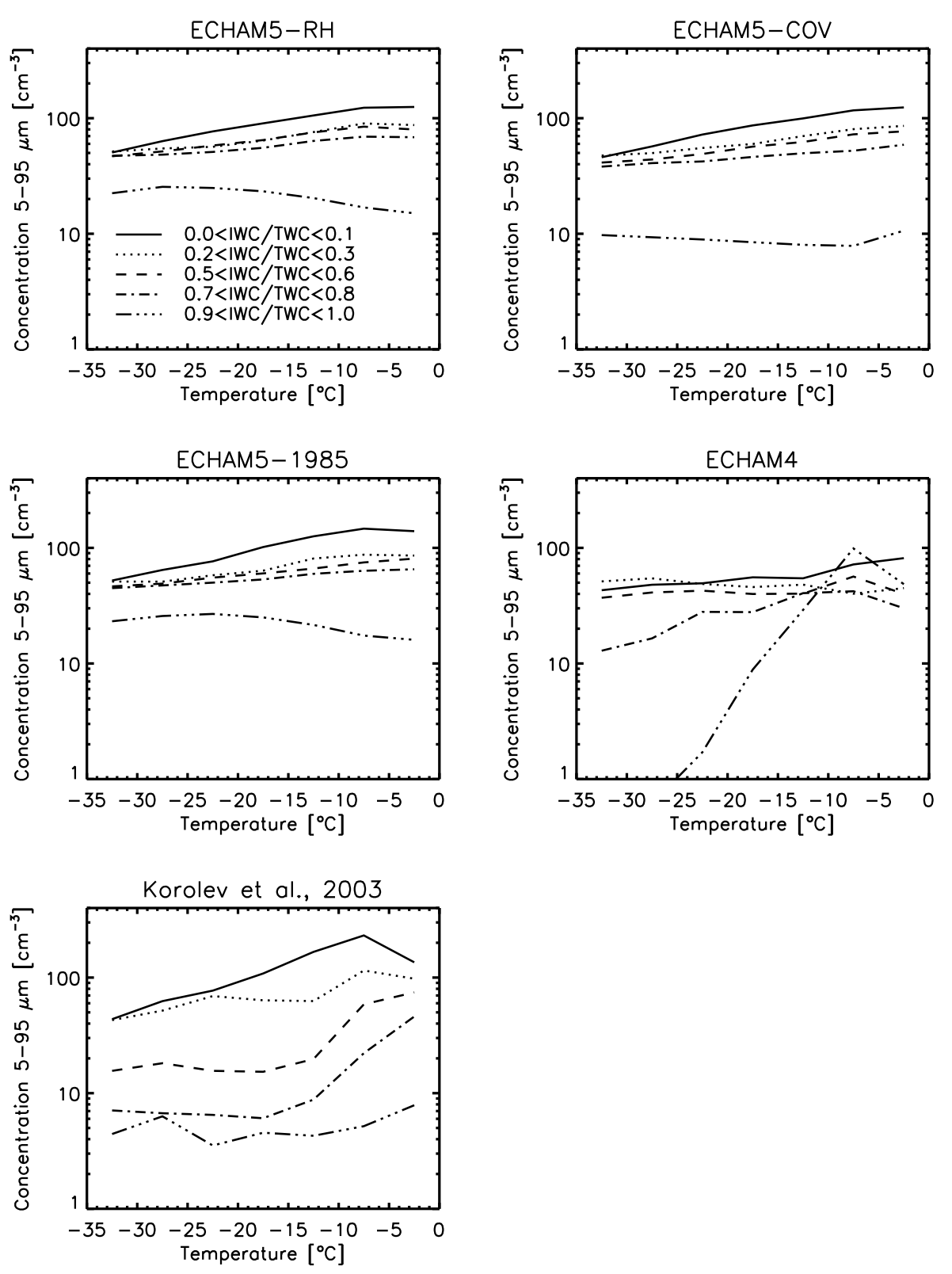

Fig. 8. In-cloud values of hydrometeor number concentration with diameters between 5-95 $\mu \mathrm{m}$ for different ratios of IWC to TWC. The observations stem from the forward scattering spectrometer probe (FSSP) that traditionally measures cloud droplets, but has also been used to measure ice crystal number concentrations, even though it has some caveats (Korolev et al., 2003).

The comparison of the ECHAM5 simulations with observations yields that the cloud droplet number concentration is generally well simulated. However, the ECHAM5 simulations overestimate the particle concentration at the highest IWC/TWC at colder temperatures pointing to an overestimate of the ice crystal number concentration. Also, the particle concentrations for intermediate IWC/TWC ratios $>0.5$ are higher than observed in all simulations. This suggests that the simulated clouds have more droplets (with higher number concentrations) and fewer ice crystals (with smaller number concentrations) than observed in clouds with intermediate IWC/TWC ratios $>0.5$.

In ECHAM4, the cloud droplet number concentration is underestimated in mixed-phase clouds despite having a much larger vertically integrated cloud droplet number concentration (cf. Table 2) because the liquid water clouds with the highest cloud droplet number concentration occur at lower altitudes in ECHAM4 as compared to ECHAM5-RH (cf. Fig. 3). At temperatures below $-20^{\circ} \mathrm{C}$ the ice crystal concentration (IWC/TWC $>0.9$ ) is severely underestimated. 
Overall, the ECHAM5 simulations agree better with observations in terms of aerosol and cloud properties than the previous model version ECHAM4.

\section{The anthropogenic aerosol effect in ECHAM5-HAM}

The total anthropogenic effect investigated in this paper is not a forcing in the IPCC's definition of aerosol radiative forcing because it includes contributions from the cloud lifetime effect and allows adjustments of atmospheric temperatures. The contribution of the cloud albedo effect, which is a pure forcing in accordance with IPCC, is estimated as explained below.

The annual global mean changes in the radiative budget at TOA and of the hydrological cycle from pre-industrial times to present-day are summarized in Table 3. The total anthropogenic aerosol effect defined as the difference in the net TOA radiation includes contributions from the direct aerosol effect, the cloud albedo effect, the cloud lifetime effect, the semi-direct effect and aerosol effects on the ice phase. However, the contribution from the glaciation effect when treating dust as montmorillonite is rather small (Lohmann and Diehl, 2006) as is the contribution from the direct effect, which amounts to $-0.27 \mathrm{~W} \mathrm{~m}^{-2}$ in ECHAM5-HAM (Schulz et al., 2006).

As summarized in Table 3, the increase in cloud cover is largest in simulation ECHAM5-COV that uses the statistical cloud cover scheme (Tompkins, 2002) and in ECHAM51985. In ECHAM5-COV, this stems from the tighter coupling of the cloud water content and cloud cover. Here an increased aerosol concentration reduces the autoconversion rate and hence enhances the condensate amount, which leads to an increased cloud fraction. In turn, the increase in cloud cover reduces the in-cloud liquid water content, which reduces the autoconversion rate and, hence, further increases the cloud condensate and cloud cover in the next timestep. Along the same lines, (Lohmann and Feichter, 1997) obtained a much larger indirect effect when the relative humidity-based cloud cover scheme by (Sundqvist et al., 1989) was replaced by the semi-empirical cloud cover scheme by (Xu and Randall, 1996) that uses both relative humidity and cloud water content as predictors for cloud cover. In ECHAM5-1985, the increase in the cloud droplet number concentration and the liquid water path is the largest of the ECHAM5 simulations and the global mean precipitation decreases the most. This results in a higher relative humidity, which in turn also increases the cloud cover.

The smaller increase in cloud cover and liquid water path in ECHAM5-RH than in ECHAM5-1985 and ECHAM5COV entails a smaller decrease in the TOA shortwave radiation of $-2 \mathrm{~W} \mathrm{~m}^{-2}$. Because of the larger cloud cover and liquid water path increase in ECHAM5-COV and ECHAM51985 , their decreases in shortwave radiations amount to $-3.2 \mathrm{~W} \mathrm{~m}^{-2}$ and $-3.3 \mathrm{~W} \mathrm{~m}^{-2}$, respectively.
The decrease in TOA shortwave radiation in ECHAM5$\mathrm{RH}$ of $-2 \mathrm{~W} \mathrm{~m}^{-2}$ is comparable to the $-1.8 \mathrm{~W} \mathrm{~m}^{-2}$ in ECHAM4. Because the increase in cloud droplet number concentration and liquid water is much higher in ECHAM4, one would expect a larger decrease in shortwave radiation than in ECHAM5-RH. The smaller decrease in shortwave radiation in ECHAM4 partly stems from the smaller increase in cloud cover as compared to ECHAM5-RH (Table 3). Secondly, because ECHAM4 only employs two spectral bands in the solar spectrum, its absorption of solar radiation by clouds is artificially enhanced by $10-15 \%$ as compared to four or more spectral bands in the solar (Wild et al., 1998). If this wrongly absorbed solar radiation was reflected, the change in shortwave radiation in ECHAM4 should be 10-15\% higher, amounting to -2 to $-2.1 \mathrm{~W} \mathrm{~m}^{-2}$.

In ECHAM4, the increase in the number of supercooled aerosols available for cirrus formation causes an increase in the cirrus ice crystal number concentration, hence reducing the outgoing longwave radiation by $0.7 \mathrm{~W} \mathrm{~m}^{-2}$ (Table 3). Because the aerosol number concentration in the pre-industrial upper troposphere is higher in ECHAM5-RH than in ECHAM4 (not shown), cirrus formation in the preindustrial atmosphere in ECHAM5 is not limited by the number of aerosols. Thus, increasing the aerosol number concentration from pre-industrial to present-day, hardly affects the number of ice crystals and hence the longwave radiation in ECHAM5-RH. Hence, it is compensating less of the reduction in shortwave radiation than in ECHAM4.

Thus, the anthropogenic aerosol effect, defined as the difference in the net TOA radiation amounts to between -1.9 and $-2.8 \mathrm{~W} \mathrm{~m}^{-2}$ in the ECHAM5 simulations. This is more than $90 \%$ larger than the $-1 \mathrm{~W} \mathrm{~m}^{-2}$ obtained with ECHAM4.

The multi-annual monthly mean change in the cloud droplet effective radius was used to calculate the forcing arising from the cloud albedo effect of water clouds. The difference in cloud droplet effective radius between present-day and pre-industrial times was added to the present-day effective radius for a second calculation of the shortwave radiation in the present-day simulation of each experiment using the present-day values of liquid water content and cloud cover. It amounts to -0.7 to $-0.8 \mathrm{~W} \mathrm{~m}^{-2}$ in the ECHAM 5 simulations. This estimate agrees well with the average value of the cloud albedo effect from IPCC (Forster et al., 2007). However, it likely represents an upper bound of the cloud albedo effect because (Feichter et al., 1997) found the cloud albedo effect to be $20 \%$ larger when calculated from monthly mean aerosol fields as compared to instantaneously calculated aerosol concentrations (Feichter et al., 1997). This is due to the non-linear relation between aerosols, clouds and the radiative fluxes.

The annual zonal mean latitude versus pressure differences of the aerosol number concentration with wet radii $>0.035 \mu \mathrm{m}$, the grid-box averaged cloud droplet and ice crystal concentration, LWC, IWC, and cloud cover from 

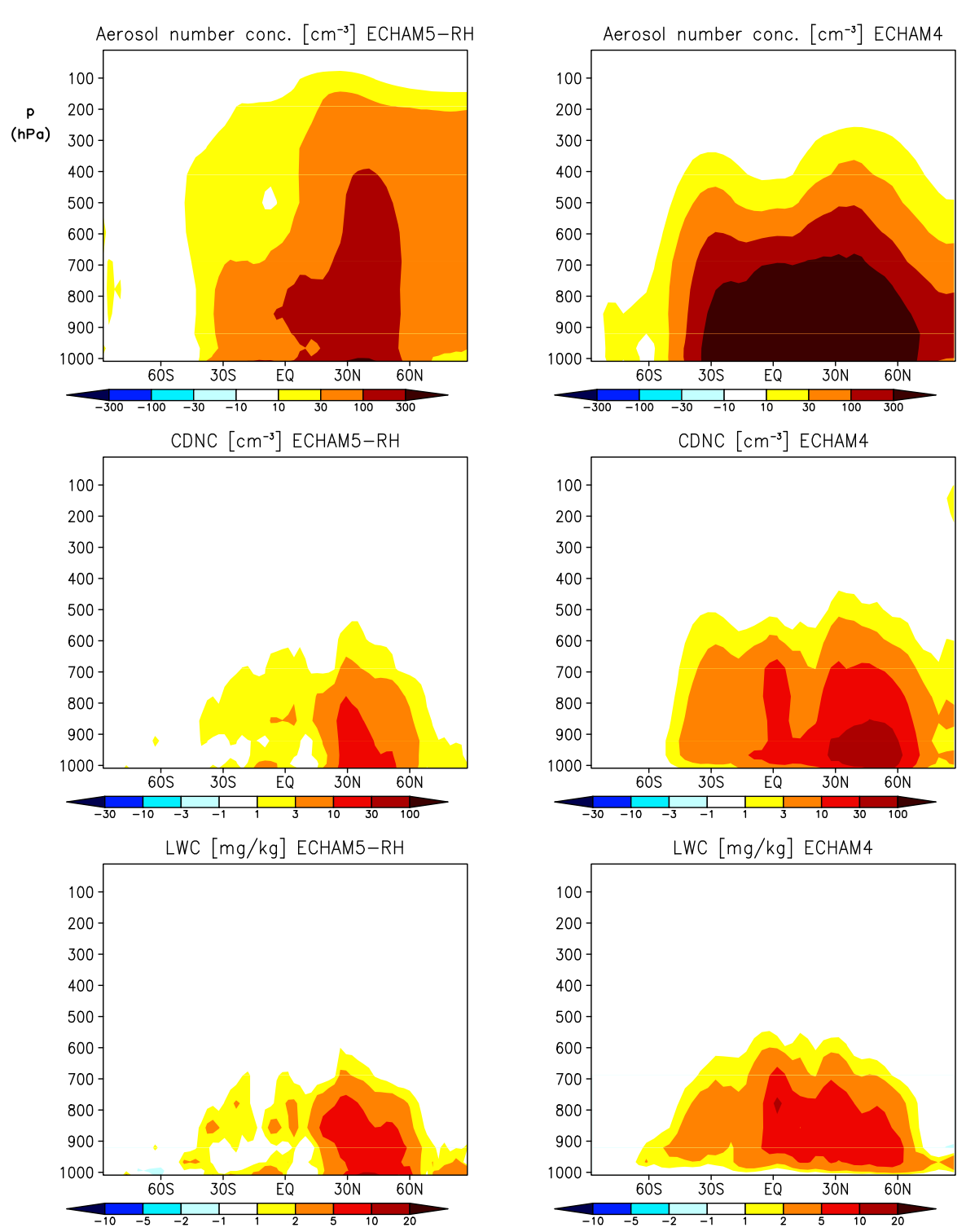

Fig. 9. Annual zonal mean latitude versus pressure differences of the aerosol number concentration with wet radii $>0.035 \mu \mathrm{m}$, the gridaverage cloud droplet number concentration (CDNC) and liquid water content (LWC) between present-day and pre-industrial times from ECHAM5-RH and from ECHAM4.

ECHAM4 and from ECHAM5-RH are shown in Figs. 9 and 10. Whereas the increase in the anthropogenic aerosol number concentration is rather uniform in the vertical in the Northern Hemisphere mid-latitudes in ECHAM5-RH, the increase in the anthropogenic aerosol number concentration is larger in ECHAM4 and is more confined to lower levels. The higher anthropogenic aerosol number concentration in the upper troposphere in ECHAM5-RH stems from homogeneous nucleation of sulfuric acid in ECHAM5-RH, a process that has not been considered in ECHAM4. On the contrary the 1985 emissions of black and organic carbon exceed the 2000 emissions by $50 \%$ and more than $100 \%$, respectively, and cause the higher anthropogenic aerosol number concentrations below $600 \mathrm{hPa}$ in ECHAM4.
As a consequence of the difference in the aerosol number concentration, the increases in CDNC and LWC in ECHAM4 are larger in the lower and mid troposphere as compared to ECHAM5-RH. The ice crystal number concentration and IWC increase between 400 and $200 \mathrm{hPa}$ in ECHAM4, especially on the Northern Hemisphere because homogeneous freezing of supercooled aerosols was limited by the number concentration of aerosols in pre-industrial times. In ECHAM5-RH, the changes in ice crystal number concentration and ice water content are less systematic, partly reflecting the less systematic changes in cloud cover (Fig. 10).

The latitudinal distributions of the changes in AOD, the hydrological cycle and in the radiation balance between preindustrial times and present-day are shown in Figs. 11 and 

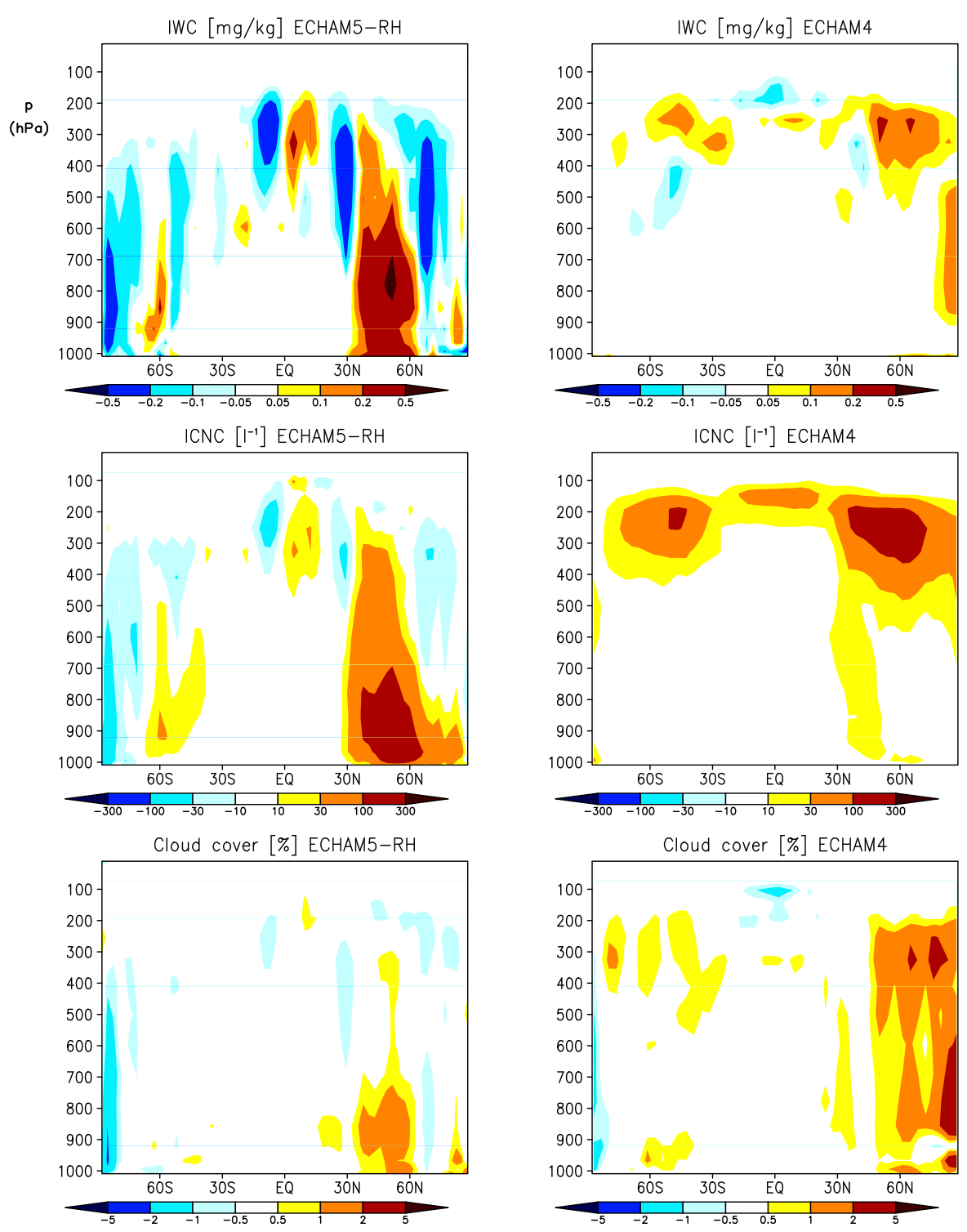

Fig. 10. As Fig. 9 but for the grid-average cloud droplet and ice crystal number concentrations (ICNC), ice water content (IWC) and cloud cover between present-day and pre-industrial times from ECHAM5-RH and from ECHAM4.

12. The increase in aerosol optical depth occurs further poleward in ECHAM4 because ECHAM4 predicts more Arctic haze in the present-day climate.

The increase in liquid water path does not mimic the increase in AOD because the increase in liquid water path stems from the retardation of the drizzle formation which depends on the cloud susceptibility. Clouds are most susceptible to changes in aerosol concentration where background cloud droplet number concentrations are the smallest, i.e. over the remote oceans. Thus, the increase in liquid water path extends further poleward than the increase in AOD. Moreover, the peaks in the increase in tropical liquid water path in simulations ECHAM5-1985 and ECHAM4 are more pronounced than the change in AOD. They result from the higher biomass burning emissions in the 1985 emission inventory. More aerosols in the tropics cause higher cloud droplet number concentrations in the detrained cloud water from convective clouds so that the stratiform part of these clouds precipitates less (Figs. 11 and 12). The changes in ice water path and total cloud cover are rather noisy and nonsystematic in ECHAM4 but consistently increase in Northern Hemisphere mid latitudes in the ECHAM5 simulations.

The increase in the cloud droplet number concentration is larger in ECHAM5-1985 than in ECHAM5-RH despite its anthropogenic AOD increase being the lowest (Table 3). This is caused by the different vertical structure of the aerosol emissions in the 1985 and 2000 emission inventories (see Sect. 3.3). In ECHAM5-1985, as in ECHAM4, the in- 

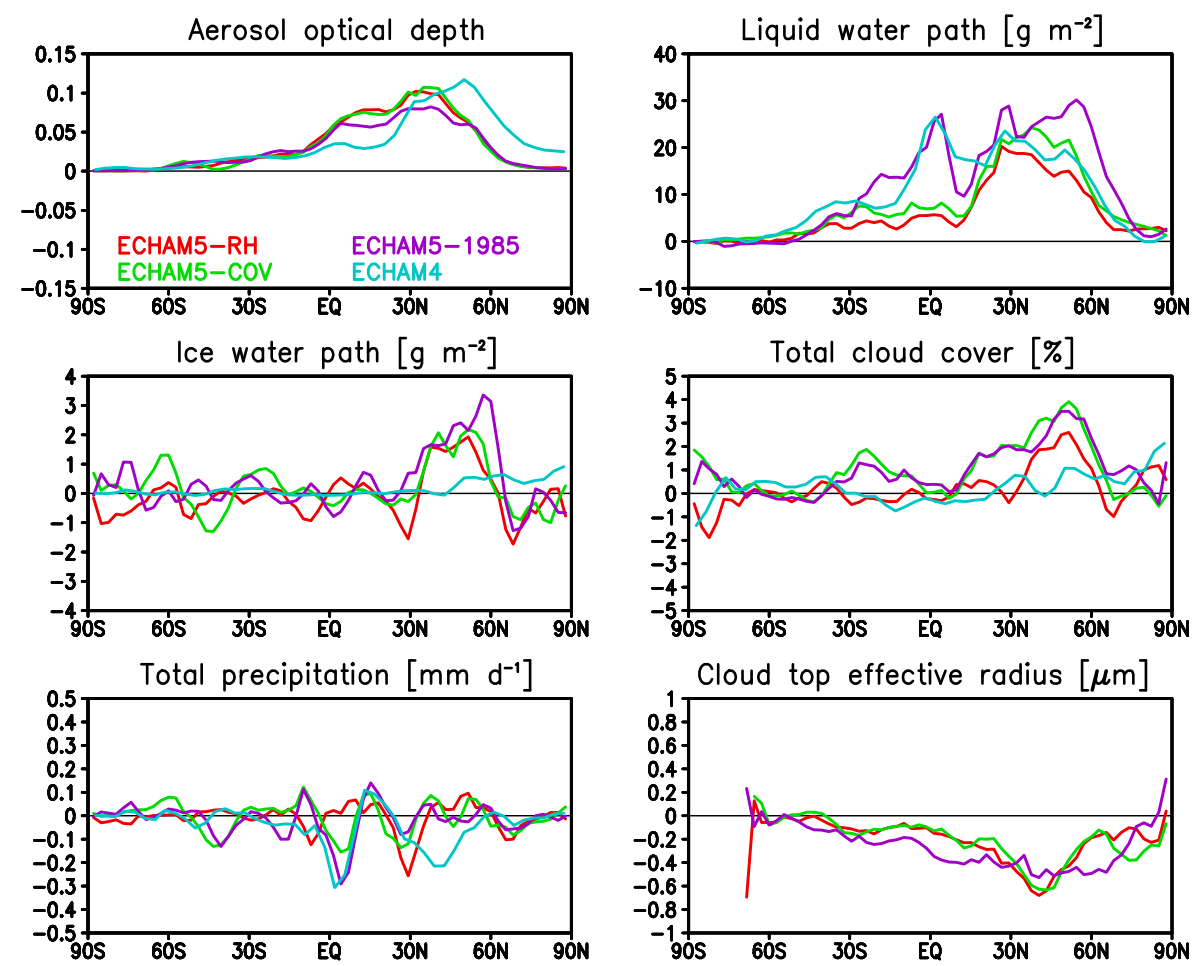

Fig. 11. Anthropogenic annual zonal mean differences of the aerosol optical depth, liquid water path, ice water path, total cloud cover, precipitation, and the cloud top effective radius from the model simulations described in Table 1. Note that the cloud top effective radius is only sampled over cloudy periods within the cloudy part of the grid box whereas all other quantities are grid-box averages and averaged over cloudy and clear periods. Note that the change in cloud top effective radius has not been diagnosed from ECHAM4.
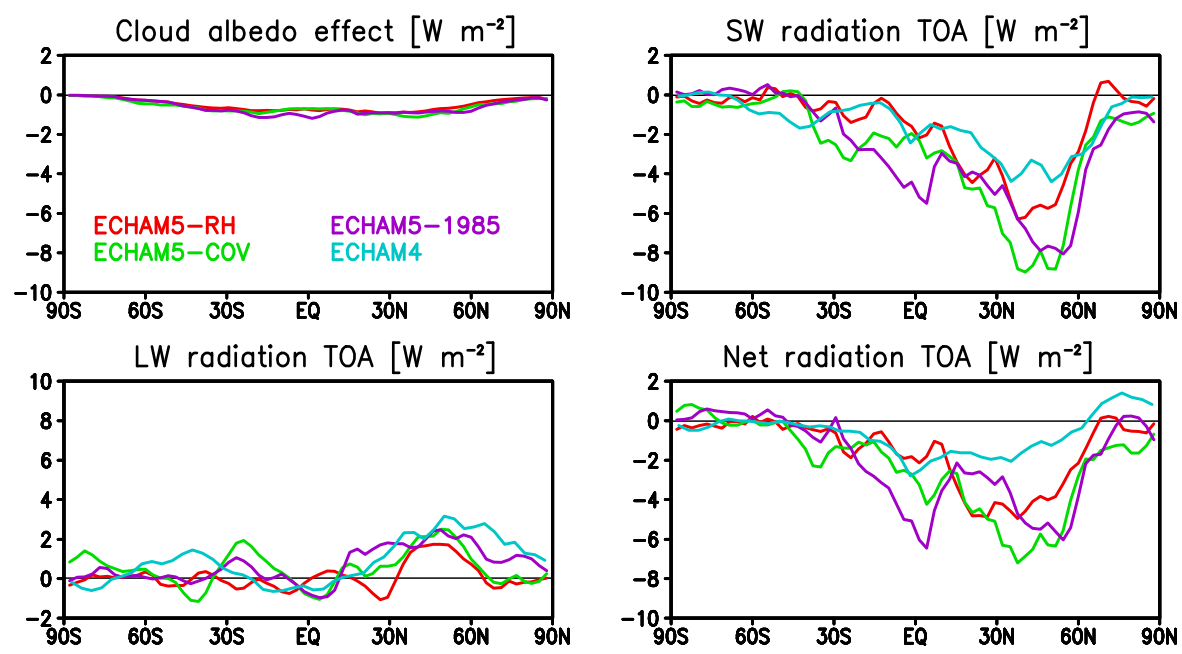

Fig. 12. As Fig. 11 but for cloud albedo effect and the anthropogenic annual zonal mean differences of the shortwave, longwave and net radiation at the top-of-the-atmosphere. Outgoing fluxes have negative signs in ECHAM, thus a positive value denotes less outgoing longwave radiation. Note that the cloud albedo effect has not been diagnosed from ECHAM4.

crease in aerosol number concentration is more limited to the boundary layer, where most water clouds are. This leads to the large increase in the cloud droplet number concentration and liquid water path in ECHAM5-1985 that is comparable to ECHAM4. Yet, the total anthropogenic aerosol effect is larger in ECHAM5-1985 than in ECHAM4 because of the larger increase in cloud cover, especially over $\mathrm{NH}$ midlatitudes (Figs. 11 and 12).

The global mean precipitation is reduced most in ECHAM4 because the Bergeron-Findeisen process is least 
efficient in this simulation as discussed in Sect. 3.4. The largest decrease in precipitation in ECHAM4 and ECHAM51985 occurs at the equator. Because more cloud water is detrained, it causes the large increase in liquid water path in the tropics in these simulations. On the contrary, the more moderate increase in liquid water path in ECHAM5-RH and ECHAM5-COV in the tropics is limited by the increase in convective precipitation (not shown).

The indirect aerosol effect can be separated into the purely radiative cloud albedo effect, which is a change in the net shortwave radiation resulting from a decrease in the cloud top effective radius and the cloud lifetime effect. As shown in Figs. 11, the cloud top effective radius sampled only over cloudy periods within the cloudy part of the grid box decreases between 0.3 and $0.6 \mu \mathrm{m}$ in mid latitudes of the Northern Hemisphere. The maximum decrease in the effective radius in ECHAM5-RH and ECHAM5-COV occurs between 35 and $50^{\circ} \mathrm{N}$ where the anthropogenic aerosol emissions are largest. The cloud albedo effect is shown in Fig. 12. It is rather similar in the ECHAM5 simulations with the largest effect of $-1.5 \mathrm{~W} \mathrm{~m}^{-2}$ between $30^{\circ} \mathrm{S}$ and $60^{\circ} \mathrm{N}$.

The much larger differences in the change in the TOA shortwave radiation between the different experiments are a result of the cloud lifetime effect. It refers to the retardation of the rain formation by the smaller cloud droplets and causes the built-up of cloud water as seen in Figs. 11 and 12. The decrease in TOA shortwave radiation is smallest in ECHAM4 because cloud cover changed the least in this simulation. On the other hand, in ECHAM5-COV and ECHAM5-1985, where the increases in cloud cover and liquid water path are larger due to the larger cloud lifetime effect, the decreases in shortwave radiation are the largest, exceeding $7 \mathrm{~W} \mathrm{~m}^{-2}$ in the mid-latitudes of the Northern Hemisphere.

Decreases in outgoing longwave radiation are most pronounced at Northern Hemisphere mid and high latitudes in ECHAM4 following the slight increase in ice water path here. As discussed above, the changes in outgoing longwave radiation are smaller in ECHAM5 due to small changes in cirrus properties. Consequently the changes in net radiation are rather similar to the changes in shortwave radiation in the ECHAM5 simulations. In ECHAM4, on the other hand, the change in TOA net radiation is generally smaller. The TOA net radiation in ECHAM4 is actually increased in the Arctic in the present-day climate because of longwave effects.

\section{Conclusions}

The double-moment cloud microphysics scheme of ECHAM4 has been coupled to the size-resolved aerosol scheme ECHAM5-HAM. The major differences between the model set-ups in ECHAM4 and the ECHAM5 version used in this study can be summarized as follows:

- ECHAM5-HAM predicts the aerosol mass and number concentration and the aerosol mixing state (Stier et al.,
2006), whereas an externally mixed aerosol number concentration was obtained from the prediction of their different mass mixing ratios in ECHAM4 (Lohmann, 2002b). ECHAM5-HAM also considers homogeneous nucleation of sulfuric acid in the upper troposphere and the subsequent microphysical growth, which is missing in ECHAM4.

- ECHAM5 has the option of employing a new cloud cover scheme that takes the subgrid-scale variability into account (Tompkins, 2002).

- The ECHAM5 radiation scheme has changed. It has more spectral bands in both the longwave and the shortwave wavelengths (Roeckner et al., 2003). It also employs a new longwave radiation code that is based on the two-stream approximation instead of the emissivity method applied in ECHAM4.

- The transport scheme for positive definite variables (water vapor, gases, aerosols, and cloud variables) has been improved. It is mass-conserving and shape-preserving in ECHAM5 (Lin and Rood, 1996).

- The parameterizations of the Bergeron-Findeisen process and of the effective ice crystal radius are improved in the simulations with the ECHAM5 double-moment scheme.

The introduction of the new aerosol microphysics scheme results in a vast increase in aerosol optical depth from ECHAM4 to ECHAM5. The aerosol optical depth in all ECHAM5 simulations is in much better agreement with observations. The ECHAM5 aerosol microphysics scheme including homogeneous nucleation of sulfuric acid in the upper troposphere yields a much better vertical aerosol distribution over continental North America.

The introduction of the new radiation scheme leads to more longwave cooling in the tropical upper troposphere. Combined with less absorption of shortwave radiation within the atmosphere, the atmosphere is less stable. The greater static instability requires more penetrative convection for compensation. This increases the global mean convective precipitation.

The liquid and ice water content as a function of temperature in mixed-phase clouds agrees better with in-situ data from aircraft campaigns in midlatitudes in the ECHAM5 simulations with the double-moment cloud microphysics scheme than in ECHAM4. This is partly caused by the different empirical formulas for the effective ice crystal radius and hence the more or less efficient aggregation process, and partly due to the more efficient Bergeron-Findeisen process in the ECHAM5 simulations with the double-moment cloud microphysics scheme. The cloud droplet and ice crystal number concentrations are also better simulated partly because the aerosol number concentration available for droplet 
nucleation is more realistic and partly because of the more efficient Bergeron-Findeisen process.

The total anthropogenic aerosol effect defined as the difference in the top-of-the-atmosphere net radiation between present-day and pre-industrial times amounts to $-1.9 \mathrm{~W} \mathrm{~m}^{-2}$ in simulation ECHAM5-RH (cf. Table 3), when the relative humidity based cloud cover scheme (Sundqvist et al., 1989) and present-day aerosol emissions representative for the year 2000 are used. It is dominated by the cloud lifetime effect. The total anthropogenic aerosol effect and the cloud lifetime effect are larger when either a statistical cloud cover scheme (Tompkins, 2002) or when a different aerosol emissions inventory, that has higher biomass burning emissions, are used. The total anthropogenic aerosol effect is larger when using the (Tompkins, 2002) scheme because an increase in cloud condensate entails an increase in cloud cover. The aerosol effect is larger when the 1985 aerosol emissions are used because in that emission inventory the black and organic carbon emissions are $50 \%$ and $120 \%$ larger than in the 2000 aerosol emission inventory.

The net anthropogenic aerosol effect at the top-of-theatmosphere is larger in ECHAM5-RH than in ECHAM4 while the decrease in shortwave radiation is comparable in both simulations. The larger increase in longwave radiation in ECHAM4 arises because the number of ice crystals in cirrus in pre-industrial conditions is limited by the available aerosol number concentration. Thus the addition of anthropogenic aerosols increases the number of ice crystals in the present-day climate in ECHAM4 and causes less longwave radiation to be emitted to space. In ECHAM5-RH, the ice crystal number concentration and ice water path hardly change when adding anthropogenic aerosols nor does the longwave radiation.

We note that the total indirect aerosol effect is unlikely to be in the vicinity of $-3 \mathrm{~W} \mathrm{~m}^{-2}$ because that would approach the positive radiative forcing due to anthropogenic increases in greenhouse gases (Forster et al., 2007). This suggest that the high black and organic carbon emissions are too large in the 1985 aerosol emission inventory and that the statistical cloud cover scheme maybe too sensitive against changes in cloud droplet number concentrations that change cloud condensate.

Acknowledgements. The authors are grateful for financial support from NCCR Climate. They thank the four anonymous reviewers and J. Feichter for helpful comments and suggestions, J. Quaas and S. Kinne for providing satellite data, A. Korolev for providing the in-situ aircraft data, and the German Computing Centre (DKRZ) and Swiss Computing Centre (CSCS) for computing time.

Edited by: B. Kärcher

\section{References}

Ackerman, A. S., Toon, O. B., Stevens, D. E., Heymsfield, A. J., Ramanathan, V., and Welton, E. J.: Reduction of tropical cloudiness by soot, Science, 288, 1042-1047, 2000.

Albrecht, B.: Aerosols, Cloud Microphysics, and Fractional Cloudiness, Science, 245, 1227-1230, 1989.

Boucher, O. and Lohmann, U.: The sulfate-CCN-cloud albedo effect: A sensitivity study with two general circulation models, Tellus B, 47, 281-300, 1995.

Brinkop, S. and Roeckner, E.: Sensitivity of a general circulation model to parameterizations of cloud-turbulence interactions in the atmospheric boundary layer., Tellus A, 47, 197-220, 1995.

Cagnazzo, C., Manzini, E., Giorgetta, M. A., De F. Forster, P. M., and Morcrette, J. J.: Impact of an improved radiation scheme in the MAECHAM5 General Circulation Model, Atmos. Chem. Phys., 7, 2503-2515, 2007, http://www.atmos-chem-phys.net/7/2503/2007/.

Dentener, F., Kinne, S., Bond, T., Boucher, O., Cofala, J., Generoso, S., Ginoux, P., Gong, S., Hoelzemann, J., Ito, A., Marelli, L., Penner, J., Putaud, J.-E., Textor, C., Schulz, M., van der Werf, G., and Wilson, J.: Emissions of primary aerosol and precursor gases in the years 2000 and 1750 prescribed data-sets for AeroCom, Atmos. Chem. Phys., 6, 4321-4344, 2006, http://www.atmos-chem-phys.net/6/4321/2006/.

Dusek, U., Frank, G. P., Hildebrandt, L., Curtius, J., Schneider, J., Walter, S., Chand, D., Drewnick, F., Hings, S., Jung, D., Borrmann, S., and Andreae, M. O.: Size matters more than chemistry for cloud-nucleating ability of aerosol particles, Science, 312, 1375-1378, 2006.

Feichter, J., Lohmann, U., and Schult, I.: The atmospheric sulfur cycle and its impact on the shortwave radiation, Clim. Dynam., 13, 235-246, 1997.

Ferraro, R., Weng, F., Grody, N., and Basist, A.: An Eight Year (1987-1994) Time Series of Rainfall, Clouds, Water Vapor, Snow-cover, and Sea-ice Derived from SSM/I Measurements, B. Am. Meteorol. Soc., 77, 891-905, 1996.

Field, P. R., Wood, R., Brown, P. R. A., Kaye, P. H., Hirst, E., Greenaway, R., and Smith, J. A.: Ice Particle Interarrival Times Measured with a Fast FSSP, J. Atmos Ocean. Techn., 20, 249261, 2003.

Forster, P., Ramaswamy, V., Artaxo, P., Berntsen, T., Betts, R., Fahey, D., Haywood, J., Lean, J., Lowe, D., Myhre, G., Nganga, J., Prinn, R., Raga, G., Schulz, M., and Van Dorland, R.: Radiative Forcing of Climate Change, in: Climate Change 2007: The Physical Science Basis. Contribution of Working Group I to the Fourth Assessment Report of the Intergovernmental Panel on Climate Change, edited by: Solomon, S., Qin, D., Manning, M., Chen, Z., Marquis, M., Averyt, K. B., Tignor, M., and Miller, H., Cambridge Univ. Press, New York, pp. 129-234, 2007.

Greenwald, T. J., Stephens, G. L., Vonder Haar, T. H., and Jackson, D. L.: A Physical Retrieval of Cloud Liquid Water Over the Global Oceans Using Special Sensor Microwave/Imager (SSM/I) Observations, J. Geophys. Res., 98, 18 471-18 488, 1993.

Hahn, C. J., Warren, S. G., and London, J.: Climatological data for clouds over the globe from surface observations, 1982-1991: The total cloud edition, Tech. rep., ORNL/CDIAC-72 NDP026A Oak Ridge National Laboratory, Oak Ridge Tennessee, USA, 1994.

Han, Q., Rossow, W. B., and Lacis, A. A.: Near-Global Survey 
of Effective Droplet Radii in Liquid Water Clouds Using ISCCP Data, J. Climate, 7, 465-497, 1994.

Han, Q., Rossow, W. B., Chou, J., and Welch, R.: Global Variation of column droplet concentration in low-level clouds, Geophys. Res. Lett., 25, 1419-1422, 1998.

Jones, A., Roberts, D. L., and Slingo, A.: A climate model study of indirect radiative forcing by anthropogenic sulphate aerosols, Nature, 370, 450-453, 1994.

Kärcher, B. and Lohmann, U.: A parameterization of cirrus cloud formation: Homogeneous freezing including effects of aerosol size, J. Geophys. Res., 107, 4698, doi:10.1029/2001JD001 429, 2002.

Kärcher, B., Hendricks, J., and Lohmann, U.: Physically based parameterization of cirrus cloud formation for use in global atmospheric models, J. Geophys. Res., 111, D01205, doi:10.1029/2005JD006219, 2006.

Khairoutdinov, M. and Kogan, Y.: A new cloud physics parameterization in a large-eddy simulation model of marine stratocumulus, Mon. Wea. Rev., 128, 229-243, 2000.

Kiehl, J. T. and Trenberth, K. E.: Earth's Annual Global Mean Energy Budget, B. Am. Meteorol. Soc., 78, 197-208, 1997.

King, M. D., Menzel, W. P., Kaufman, Y. J., Tanre, D., Gao, B. C., Platnick, S., Ackerman, S. A., Remer, L. A., Pincus, R., and Hubanks, P. A.: Cloud and aerosol properties, precipitable water, and profiles of temperature and water vapor from MODIS, IEEE Trans. Geo. Rem. Sens., 41, 442-458, 2003.

Korolev, A. V. and Isaac, G. A.: Roundness and aspect ratio of particles in ice clouds, J. Atmos. Sci., 60, 1795-1808, 2003.

Korolev, A. V. and Isaac, G. A.: Relative humidity in liquid, mixedphase, and ice clouds, J. Atmos. Sci., 63, 2865-2880, 2006.

Korolev, A. V., Strapp, J. W., Isaac, G. A., and Nevzorov, A. N.: The Nevzorov airborne hot-wire LWC-TWC probe: principle of operation and performance characteristics, J. Atmos. Ocea. Tech., 15, 1495-1510, 1998.

Korolev, A. V., Isaac, G. A., Cober, S. G., Strapp, W., and Hallett, J.: Microphysical characterization of mixed-phase clouds, Q. J. Roy. Meteor. Soc., 129, 39-65, 2003.

Lin, H. and Leaitch, W. R.: Development of an in-cloud aerosol activation parameterization for climate modelling, in: Proceedings of the WMO Workshop on Measurement of Cloud Properties for Forecasts of Weather, Air Quality and Climate, World Meteorol. Organ., Geneva, pp. 328-335, 1997.

Lin, S. J. and Rood, R. B.: Multidimensional flux-form semiLagrangian transport schemes, Mon. Wea. Rev., 124, 20462070, 1996.

Liousse, C., Penner, J. E., Chuang, C., Walton, J. J., Eddleman, H., and Cachier, H.: A global three-dimensional model study of carbonaceous aerosols, J. Geophys. Res., 101, 19411-19432, 1996.

Lohmann, U.: A glaciation indirect aerosol effect caused by soot aerosols, Geophys. Res. Lett., 29, 1052, doi:10.1029/2001GL014357, 2002a.

Lohmann, U.: Possible aerosol effects on ice clouds via contact nucleation, J. Atmos. Sci., 59, 647-656, 2002 b.

Lohmann, U. and Diehl, K.: Sensitivity studies of the importance of dust ice nuclei for the indirect aerosol effect on stratiform mixedphase clouds, J. Atmos. Sci., 63, 968-982, 2006.

Lohmann, U. and Feichter, J.: Impact of sulfate aerosols on albedo and lifetime of clouds: A sensitivity study with the ECHAM
GCM, J. Geophys. Res., 102, 13 685-13 700, 1997.

Lohmann, U. and Feichter, J.: Global indirect aerosol effects: A review, Atmos. Chem. Phys., 5, 715-737, 2005, http://www.atmos-chem-phys.net/5/715/2005/.

Lohmann, U. and Kärcher, B.: First interactive simulations of cirrus clouds formed by homogeneous freezing in the ECHAM GCM, J. Geophys. Res., 107, 4105, doi:10.1029/2001JD000 767, 2002.

Lohmann, U. and Roeckner, E.: The influence of cirrus cloudradiative forcing on climate and climate sensitivity in a general circulation model, J. Geophys. Res., 100, 16305-16323, 1995.

Lohmann, U. and Roeckner, E.: Design and performance of a new cloud microphysics scheme developed for the ECHAM general circulation model, Clim. Dynam., 12, 557-572, 1996.

Lohmann, U., Feichter, J., Chuang, C. C., and Penner, J. E.: Predicting the number of cloud droplets in the ECHAM GCM, J. Geophys. Res., 104, 9169-9198, 1999.

Lohmann, U., Kärcher, B., and Hendricks, J.: Sensitivity studies of cirrus clouds formed by heterogeneous freezing in the ECHAM GCM, J. Geophys. Res, 109, D16204, doi:10.1029/2003JD004 443, 2004.

Mlawer, E. J., Taubman, S. J., Brown, P. D., Iacono, M. J., and Clough, S. A.: Radiative transfer for inhomogeneous atmospheres: RRTM, a validated correlated-k model for the longwave, J. Geophys. Res., 102, 16 663-16682, 1997.

Monahan, E. C., Spiel, D. E., and Davidson, K. L.: A model of marine aerosol generation via whitecaps and wave disruption, in: Oceanic Whitecaps, edited by: Monahan, E. C. and MacNiocaill, G., D. Reidel, Norwell, Mass., 1986.

Peng, Y. and Lohmann, U.: Sensitivity study of the spectral dispersion of the cloud droplet size distribution on the indirect aerosol effect, Geophys. Res. Lett., 30, 1507, doi:10.1029/2003GL017 192, 2003.

Penner, J. E., Zhang, S. Y., and Chuang, C. C.: Soot and smoke aerosol may not warm climate, J. Geophys. Res., 108, 4657, doi:10.1029/2003JD003 409, 2003.

Quante, M.: The role of clouds in the climate system, Journal De Physique Iv, 121, 61-86, 2004.

Roeckner, E., Arpe, K., Bengtsson, L., Christoph, M., Claussen, M., Dümenil, L., Esch, M., Giorgetta, M., Schlese, U., and Schulzweida, U.: The atmospheric general circulation model ECHAM4: Model description and simulation of the present day climate, Tech. Rep., 218, Max-Planck-Inst. für Meteorol., Hamburg, Germany, 1996.

Roeckner, E., Bäuml, G., Bonaventura, L., Brokopf, R., Esch, M., Giorgetta, M., Hagemann, S., Kirchner, I., Kornblueh, L., Manzini, E., Rhodin, A., Schlese, U., Schulzweida, U., and Tompkins, A.: The atmospheric general circulation model ECHAM5. PART I: Model description, Tech. Rep. 349, MaxPlanck-Inst. für Meteorol., Hamburg, Germany, 2003.

Rogers, R. R. and Yau, M. K.: A Short Course in Cloud Physics, Pergamon, Tarrytown, N. Y., 1989.

Rossow, W. B. and Schiffer, R. A.: Advances in understanding clouds from ISCCP, B. Am. Meteorol. Soc., 80, 2261-2287, 1999.

Schulz, M., Textor, C., Kinne, S., Balkanski, Y., Bauer, S., Berntsen, T., Berglen, T., Boucher, O., Dentener, F., Guibert, S., Isaksen, I. S. A., Iversen, T., Koch, D., Kirkevag, A., Liu, X., Montanaro, V., Myhre, G., Penner, J. E., Pitari, G., Reddy, S., Seland, O., Stier, P., and Takemura, T.: Radiative forc- 
ing by aerosols as derived from the AeroCom present-day and pre-industrial simulations, Atmos. Chem. Phys., 6, 5225-5246, 2006, http://www.atmos-chem-phys.net/6/5225/2006/.

Schwarz, J. P., Gao, R. S., Fahey, D. W., Thomson, D. S., Watts, L. A., Wilson, J. C., Reeves, J. M., Darbeheshti, M., Baumgardner, D. G., Kok, G. L., Chung, S. H., Schulz, M., Hendricks, J., Lauer, A., Karcher, B., Slowik, J. G., Rosenlof, K. H., Thompson, T. L., Langford, A. O., Loewenstein, M., and Aikin, K. C.: Single-particle measurements of midlatitude black carbon and light-scattering aerosols from the boundary layer to the lower stratosphere, J. Geophys. Res., 111, D16207, doi:10.1029/2006JD007076, 2006.

Scott, N. A., Chedin, A., Armante, R., Francis, J., Stubenrauch, C., Chaboureau, J. P., Chevallier, F., Claud, C., and Cheruy, F.: Characteristics of the TOVS Pathfinder Path-B dataset, B. Am. Meteorol. Soc., 80, 2679-2701, 1999.

Smith, M. H. and Harrison, N.: The sea spray generation function, J. Aerosol Sci., 29, 189-190, 1998.

Stier, P., Feichter, J., Kinne, S., Kloster, S., Vignati, E., Wilson, J., Ganzeveld, L., Tegen, I., Werner, M., Balkanski, Y., Schulz, M., Boucher, O., Minikin, A., and Petzold, A.: The aerosolclimate model ECHAM5-HAM, Atmos. Chem. Phys., 5, 11251156, 2005, http://www.atmos-chem-phys.net/5/1125/2005/.

Stier, P., Feichter, J., Kloster, S., Vignati, E., and Wilson, J.: Emission-induced nonlinearities in the global aerosol system results from the ECHAM5-HAM aerosol-climate model, J. Climate, 19, 3845-3862, 2006.

Stier, P., Seinfeld, J., Kinne, S., and Boucher, O.: Aerosol absorption and radiative forcing, Atmos. Chem. Phys. Discuss., 7, 7171-7233, 2007,

http://www.atmos-chem-phys-discuss.net/7/7171/2007/.
Storelvmo, T., Kristjansson, J.-E., and Lohmann, U.: Aerosol influence on mixed-phase clouds in CAM-Oslo, J. Atmos. Sci., accepted, 2007.

Sundqvist, H., Berge, E., and Kristiansson, J. E.: Condensation and Cloud Parameterization Studies with a Mesoscale Numerical Weather Prediction Model, Mon. Wea. Rev., 117, 1641-1657, 1989.

Susskind, J., Piraino, P., Rokke, L., Iredell, T., and Mehta, A.: Characteristics of the TOVS Pathfinder Path A dataset, B. Am. Meteorol. Soc., 78, 1449-1472, 1997.

Tompkins, A. M.: A prognostic parameterization for the subgridscale variability of water vapor and clouds in large-scale models and its use to diagnose cloud cover, J. Atmos. Sci., 59, 19171942, 2002.

Twomey, S. A.: The influence of pollution on the shortwave albedo of clouds, J. Atmos. Sci., 34, 1149-1152, 1977.

Weng, F. and Grody, N. C.: Retrieval of cloud liquid water using the special sensor microwave imager (SSM/I), J. Geophys. Res., 99, 25 535-25 551, 1994.

Wild, M. and Roeckner, E.: Radiative fluxes in the ECHAM5 general circulation model, J. Climate, 19, 3792-3809, 2006.

Wild, M., Ohmura, A., Gilgen, H., Roeckner, E., Giorgetta, M., and Morcrette, J.-J.: The disposition of radiative energy in the global climate system: GCM-calculated versus observational data, Clim. Dynam., 14, 853-869, 1998.

Xu, K.-M. and Randall, D. A.: A Semiempirical cloudiness parameterizations for use in climate models, J. Atmos. Sci., 53, 30843102, 1996. 